\title{
molecules
}

ISSN 1420-3049

www.mdpi.com/journal/molecules

Article

\section{A Modular Approach to Triazole-Containing Chemical Inducers of Dimerisation for Yeast Three-Hybrid Screening}

\author{
Fanny Tran ${ }^{1}$, Anahi V. Odell ${ }^{2}$, Gary E. Ward ${ }^{2, *}$ and Nicholas J. Westwood $^{1, *}$
}

1 School of Chemistry and Biomolecular Sciences Research Complex, University of St Andrews and EaStCHEM, North Haugh, St Andrews, Fife, Scotland KY16 9ST, UK

2 Department of Microbiology and Molecular Genetics, 316 Stafford Hall, University of Vermont, 95 Carrigan Drive, Burlington, VT 05405, USA

* Authors to whom correspondence should be addressed; E-Mails: njw3@st-andrews.ac.uk; gward@uvm.edu; Tel.: +44-(0)1334-46316 (N.J.W.); +1-802-656-4868 (G.E.W.); Fax: +44-(0)1334-462595 (N.J.W.); +1-802-656-8749 (G.E.W.).

Received: 1 August 2013; in revised form: 5 September 2013 / Accepted: 6 September 2013 / Published: 23 September 2013

\begin{abstract}
The yeast three-hybrid ( $\mathrm{Y} 3 \mathrm{H})$ approach shows considerable promise for the unbiased identification of novel small molecule-protein interactions. In recent years, it has been successfully used to link a number of bioactive molecules to novel protein binding partners. However despite its potential importance as a protein target identification method, the $\mathrm{Y} 3 \mathrm{H}$ technique has not yet been widely adopted, in part due to the challenges associated with the synthesis of the complex chemical inducers of dimerisation (CIDs). The development of a modular approach using potentially "off the shelf" synthetic components was achieved and allowed the synthesis of a family of four triazole-containing CIDs, MTX-Cmpd2.2-2.5. These CIDs were then compared using the $\mathrm{Y} 3 \mathrm{H}$ approach with three of them giving a strong positive interaction with a known target of compound 2 , TgCDPK1. These results showed that the modular nature of our synthetic strategy may help to overcome the challenges currently encountered with CID synthesis and should contribute to the $\mathrm{Y} 3 \mathrm{H}$ approach reaching its full potential as an unbiased target identification strategy.
\end{abstract}

Keywords: click chemistry; yeast three-hybrid approach; CIDs 


\section{Introduction}

The yeast three-hybrid ( $\mathrm{Y} 3 \mathrm{H})$ approach shows considerable promise for the identification of novel small molecule-protein interactions [1-17]. In recent years, this unbiased approach has linked a number of bioactive molecules to novel protein binding partners generating new biological hypotheses that have been investigated further using alternative experimental techniques $[2,3,6,9,13]$. For example, Johnsson discovered using $\mathrm{Y} 3 \mathrm{H}$ that sulfasalazine, a drug used against inflammatory bowel disease, inhibits tetrahydrobiopterin biosynthesis and consequently nitric oxide production through its interaction with sepiapterin reductase [6]. More recently, Cornish used Y3H to identify PDE6D as a novel protein target of anecortave acetate, an intraocular pressure-lowering agent used in the treatment of glaucoma [18]. At the heart of the $\mathrm{Y} 3 \mathrm{H}$ approach is an ingenious system to screen for potential binding proteins [13,15,19-22]. The screen is carried out in yeast cells as the successful formation of a ternary complex consisting of the bait, the target protein and a chemical inducer of dimerisation (CID) results in yeast cell growth via the activation of the required yeast reporter gene (see Figure 1 for details). The availability of the CID, a compound that contains the bioactive molecule of interest, a linker unit and typically methotrexate (MTX) is essential.

Figure 1. Schematic representation of the $\mathrm{Y} 3 \mathrm{H}$ system used in this study showing the ternary complex between the chemical inducer of dimerization (CID) and the two fusion proteins containing the activation and DNA-binding domains of the transcription factor (AD and DBD, respectively). The CID consists of: (i) methotrexate (shown in purple), which binds to the dihydrofolate reductase DHFR-DBD fusion protein; (ii) a flexible linker unit (black line) and (iii) the bioactive molecule of interest (blue hexagon), which binds to the target protein-AD fusion. Successful formation of the ternary complex results in expression of the reporter genes (e.g., $L E U 2)$ that enables the yeast cell to grow in the absence of the amino acid.

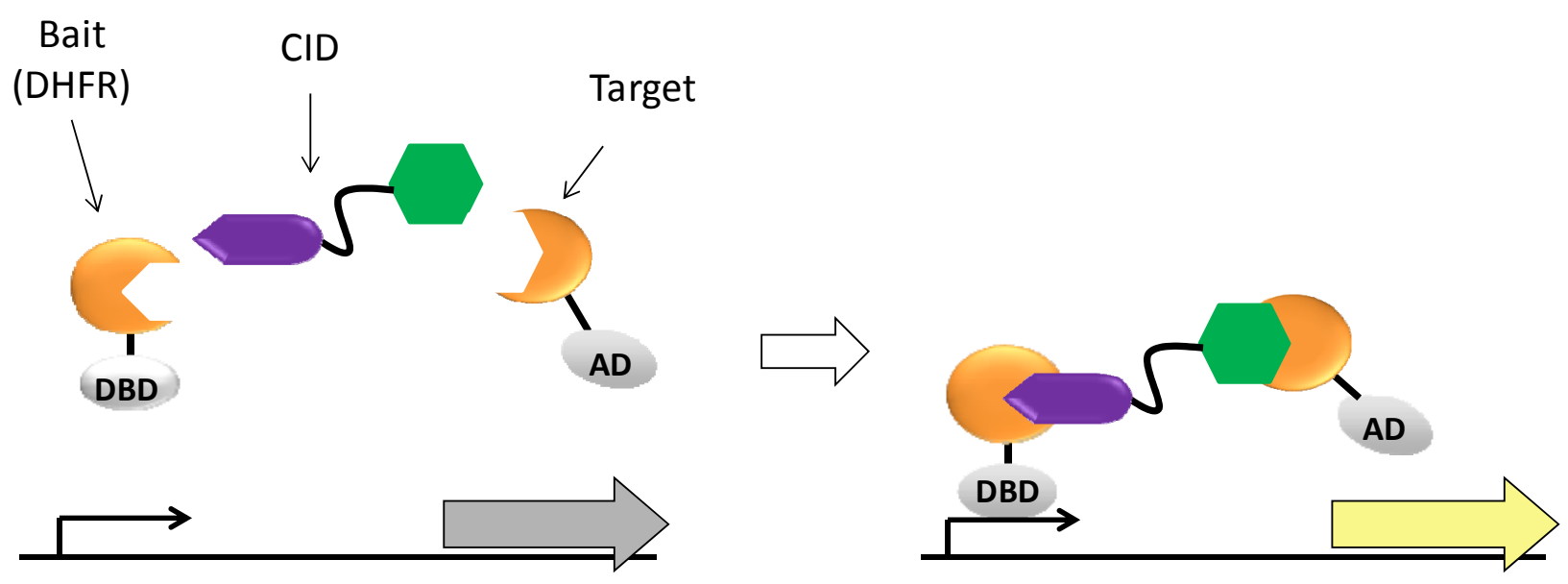

Despite its potential importance as a protein target identification method, the $\mathrm{Y} 3 \mathrm{H}$ technique has not yet been widely adopted in part due to the challenges associated with the synthesis of the high molecular weight $(>1,000 \mathrm{Da})$ and relatively complicated CIDs. For example, we recently reported the use of $\mathrm{Y} 3 \mathrm{H}$ to identify $\mathrm{TgBRADIN}$ as a target of compound 2 [23]. $\operatorname{Tg} B R A D I N$ is a previously unknown negative regulator of the apicomplexan parasite Toxoplasma gondii's tachyzoite to bradyzoite 
differentiation pathway. In that study we used a CID that contained a PEG linker unit MTX-Cmpd2.1 (Figure 2A), in line with the majority of the existing literature [3,6,11,24]. MTX-Cmpd2.1 was prepared in a total of 21 steps with seven of the steps being required just to make the linker unit.

Figure 2. Structures of (A) CID MTX-Cmpd2.1 bearing a PEG linker and (B) the erlotinib-based CID as described by Chidley et al. [6].

(A)

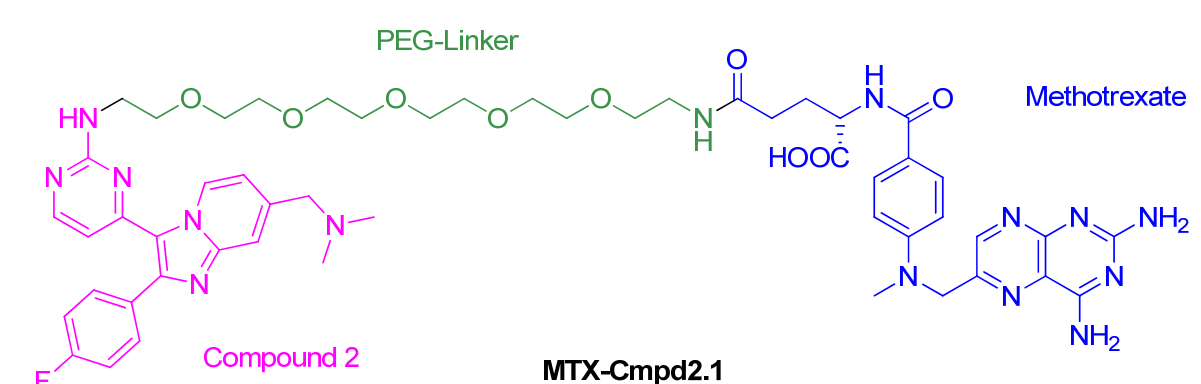

(B)

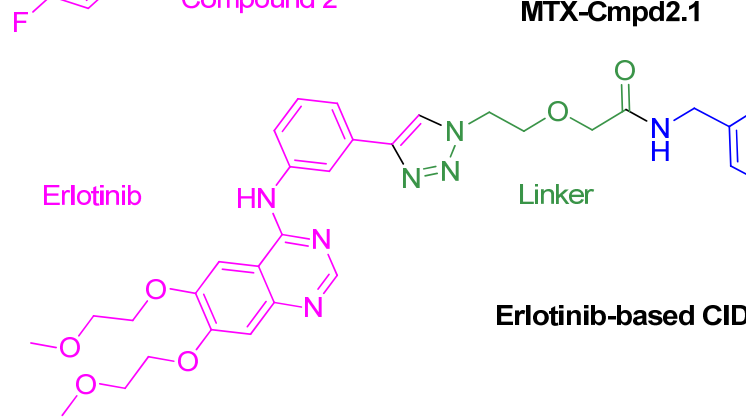

In the course of our $\mathrm{Y} 3 \mathrm{H}$ project, we became interested in preparing additional CIDs that contained the same bioactive molecule (compound 2) and methotrexate but that differed in the length of the linker. The question of whether linker length affects the ability of a CID to dimerise proteins has been previously examined in three-hybrid systems, but with conflicting results $[19,25,26]$. For example, the length of the linker appeared to have no effect on the dimerisation of FK506-binding proteins leading to signal transduction [26]. Similarly, Cornish saw high levels of transcriptional activation induced in the $\mathrm{Y} 3 \mathrm{H}$ system using dihydrofolate reductase and the glucocorticoid receptor, regardless of CID structure and linker length [19]. In contrast, Amara et al. found dramatic effects of the linker length when comparing the ability of a series of four CIDs to dimerize tandem FKBP fused either to Fas proteins leading to apoptosis or to the domains of a transcription factor allowing reporter gene transcription [25]. The discrepancies between these studies might be explained by the relative strength of the interactions, the distance between the two proteins required to exert their effects or steric hindrance imposed by the proteins. Unfortunately these variables are extremely difficult to anticipate when designing a CID for use in $\mathrm{Y} 3 \mathrm{H}$-based drug target identification, suggesting that the development of a versatile synthetic strategy to enable the rapid generation of related CIDs (families of CIDs) may be advantageous. We therefore decided to establish a route to families of compound 2-based CIDs that differed only in the linker unit using potentially "off the shelf" reagents.

In 2011, Johnsson reported the synthesis of a 1,2,3-triazole-containing CID based on the clinically approved drug erlotinib (Figure 2B). Use of this CID in $\mathrm{Y} 3 \mathrm{H}$ enabled the identification of the binding partner oxysterol-binding protein-related protein 7, the first non-kinase target identified for this drug [6]. 
Based on this literature precedent, we investigated the use of the copper-catalysed Hüisgen 1,3-dipolar cycloaddition reaction between an azide and an alkyne to generate CIDs in a modular fashion. Here we report the application of this approach to the rapid synthesis of a family of four CIDs with varying linker lengths, MTX-Cmpd2.2-2.5 (Scheme 1). A comparison of our CIDs MTXCmpd2.1-2.5 in the Y3H approach is also described. Significantly, lower background growth was observed with some of our new triazole-containing CIDs than with our original PEG-containing CID, MTX-Cmpd2.1.

\section{Results and Discussion}

An outline of the modular approach that was adopted to target MTX-Cmpd2 CIDs is shown in Scheme 1. The planned synthesis involved the coupling of two key components: the compound 2-based alkyne 3 (where $\mathrm{n}$ is variable) and the ${ }^{t} \mathrm{Bu}$-MTX-azide $\mathbf{4}$ (where $\mathrm{m}$ is variable). Components 3 and $\mathbf{4}$ could be accessed by the synthesis of a precursor to compounds $\mathbf{2}$ and $\mathbf{5}$, various PEG-based linker units 6 and 7 and tert-butyl methotrexate ( ${ }^{t}$ Bu-MTX, 8 [23]) (Scheme 1).

Scheme 1. Modular approach to MTX-Cmpd2 CIDs enabling components to be mixed and matched as required.
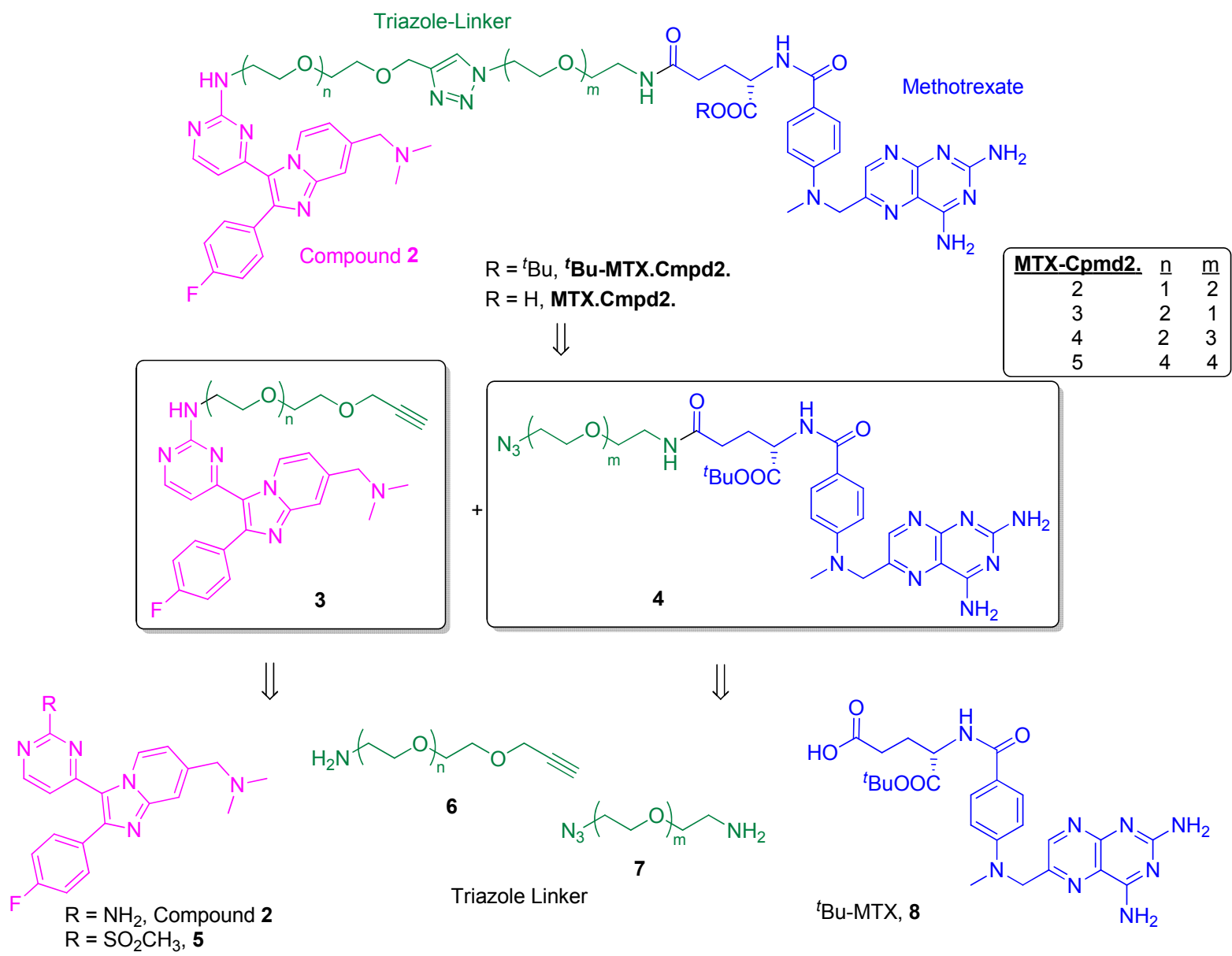

To determine whether the synthetic plan would work and to assess whether a triazole-containing linker could be tolerated in this system, initial studies focused on the synthesis of MTX-Cmpd2.2 ( $\mathrm{n}=1$ and $\mathrm{m}=2$ ), which was close in structure to the original CID MTX-Cmpd2.1. 3D Representations 
of MTX-Cmpd2.1 and MTX-Cmpd2.2 (generated using low level computational methods inspired by the report of Lu et al. [27]) suggested that the planned change in the linker system would give CID MTX-Cmpd2.2, with little significant impact on the overall length of the CID despite the fact that the linker unit in MTX-Cmpd2.2 contains an additional atom. Again in agreement with the work of $\mathrm{Lu}$ et al. [27], the predicted extended conformation of MTX-Cmpd2.1 was linear, whereas that for MTX-Cmpd2.2 was not (Figure 3).

Figure 3. Examples of predicted 3D conformations of (A) MTX-Cmpd2.1 and (B) MTX-Cmpd2.2.

(A)

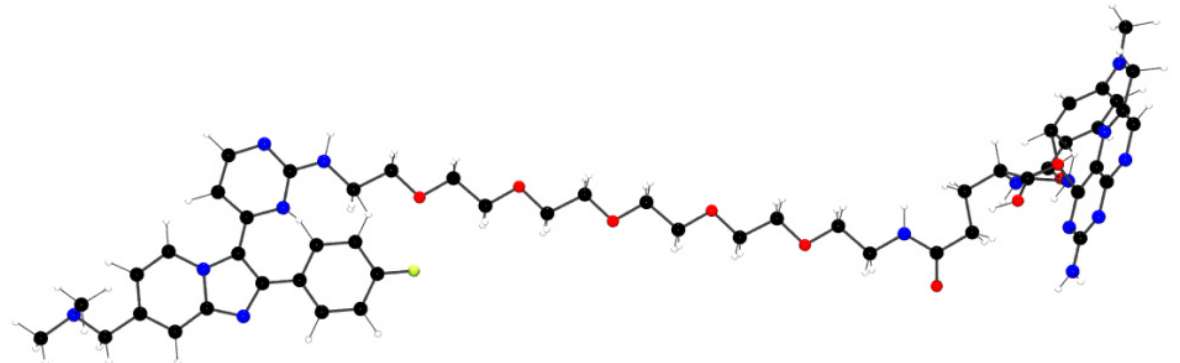

(B)

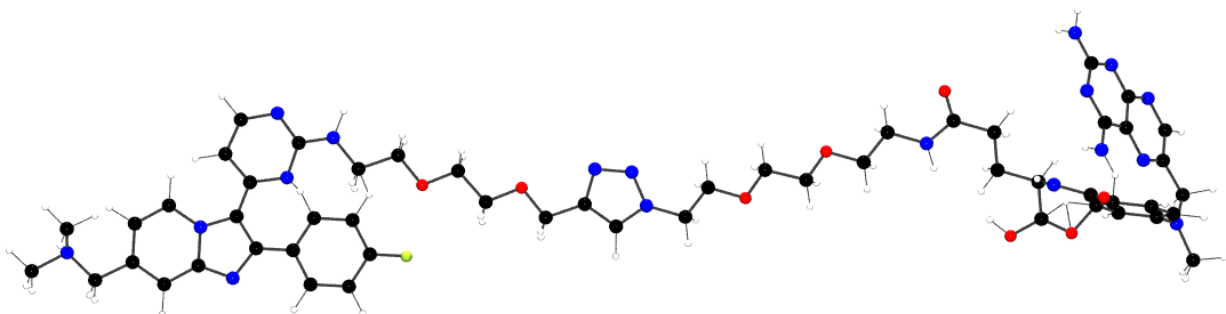

\subsection{Comparison of MTX-Cmpd2.1 (PEG Linker) and MTX-Cmpd2.2 (Triazole Linker)}

\subsubsection{Synthesis of the Compound 2-based Alkynes 3}

The required sulfone $\mathbf{5}$ was successfully synthesised in gram quantities as reported previously by us and others $[9,23,28]$. The required aminoalkyne linker $6 \mathbf{a}$ was then prepared in multi-gram quantities starting with selective propargylation of diethylene glycol 9a. Subsequent tosylation of the remaining alcohol functionality [29] followed by treatment with $\mathrm{NaN}_{3}$ in the presence of TBAI afforded the corresponding azidoalkyne [30], which was reduced under Staudinger reduction conditions using solid phase triphenylphosphine to give $6 \mathbf{a}$ (Scheme 2A) [24]. The linker 6a was then reacted with sulfone 5 at $110^{\circ} \mathrm{C}$ using microwave irradiation to afford $\mathbf{3 a}$ (Scheme $2 \mathrm{~A}$ ).

\subsubsection{Synthesis of the ${ }^{t} \mathrm{Bu}-\mathrm{MTX}$-Azides 4}

tert-Butyl methotrexate $\mathbf{8}$ was prepared in gram quantities according to literature methods [23]. The aminoalkyne linker $\mathbf{7 b}$ was synthesised in an analogous manner to aminoalkyne linker $\mathbf{6 a}$. Triethylene glycol 9b was converted to the ditosylated analogue [29] and treated with $\mathrm{NaN}_{3}$ to afford the corresponding diazide [30] (Scheme 2B). Staudinger reduction of one of the diazide groups in the presence of 1 equivalent of $\mathrm{PPh}_{3}$ and $1 \mathrm{~N} \mathrm{HCl}$ afforded a pure sample of $\mathbf{7 b}$ following an acid-base work-up [31]. Aminoazide $\mathbf{7 b}$ was then coupled to ${ }^{t}$ Bu-MTX 8 to give $\mathbf{4 b}$ (Scheme 2B). 
Scheme 2. Synthesis of (A) Compound 2 based alkyne 3 and (B) ${ }^{t}$ Bu-MTX azide 4.

(A)
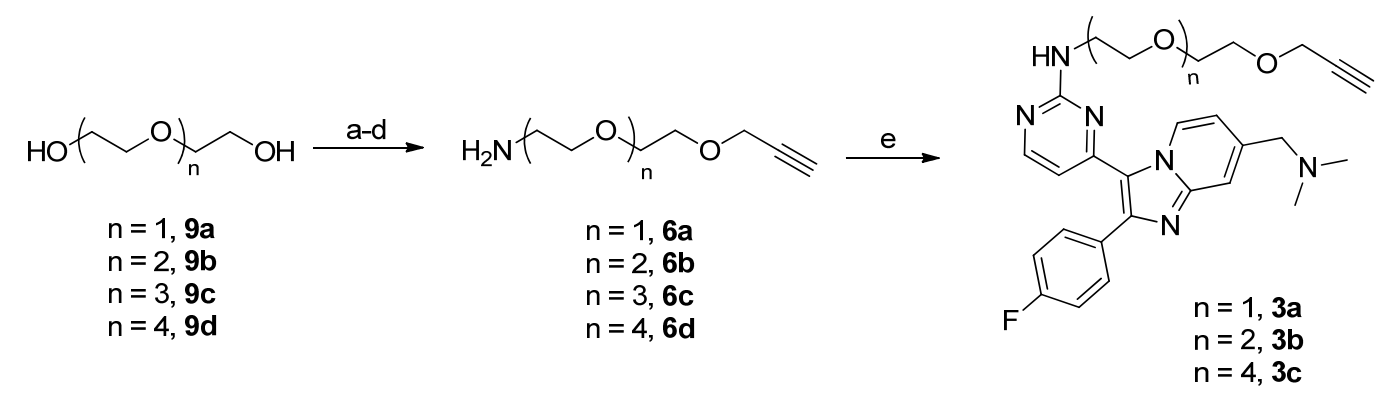

a. i. $\mathrm{NaH}, \mathrm{DMF}, 0^{\circ} \mathrm{C}$; ii. propargyl bromide, rt, o/n; b. TsCl, $\mathrm{KOH}, \mathrm{DMF}, 0^{\circ} \mathrm{C}$ to rt, o/n; $\mathrm{c} . \mathrm{NaN}_{3}$, DMF, TBAI, $120^{\circ} \mathrm{C}, \mathrm{o} / \mathrm{n}$; d. i) $\mathrm{PS}-\mathrm{PPh}_{3}, \mathrm{THF}, \mathrm{o} / \mathrm{n}$; ii) $\mathrm{H}_{2} \mathrm{O}$, rt, o/n, yields over 4 steps: $\mathbf{6 a}=27 \%, \mathbf{6 b}=31 \%, \mathbf{6 c}=\mathbf{2 8 \%}, \mathbf{6 d}$ $=46 \%$; e. $5, \mathrm{CH}_{3} \mathrm{CN}$, microwave, $110^{\circ} \mathrm{C}, 4 \mathrm{~h}, 3 \mathrm{a}=62 \%, 3 \mathrm{~b}=62 \%, 3 \mathrm{c}=60 \%$.

(B)

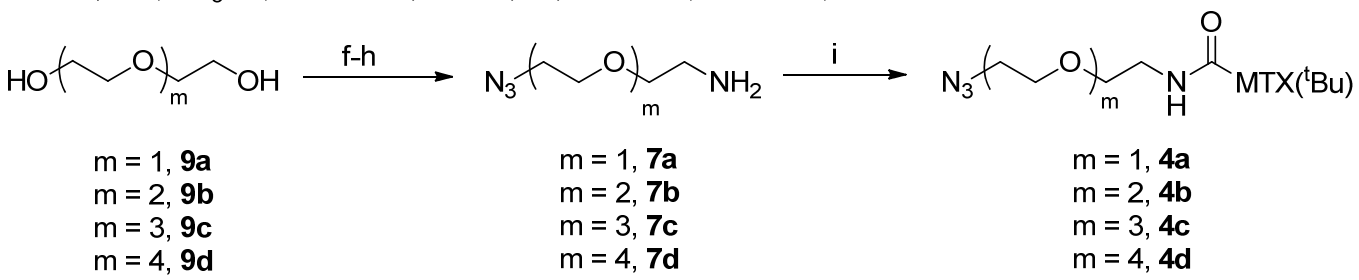

f. TsCl, $\mathrm{KOH}, \mathrm{DMF}, \mathrm{rt}, \mathrm{o} / \mathrm{n}$; g. $\mathrm{NaN}_{3}$, DMF, TBAI, $120^{\circ} \mathrm{C}$; o/n; h. $\mathrm{PPh}_{3}, \mathrm{HCl}(1 \mathrm{~N}), \mathrm{Et}_{2} \mathrm{O} / \mathrm{THF}$, rt, o/n, yields over 3 steps, $\mathbf{7 a}=40 \%, 7 \mathbf{b}=35 \%, 7 \mathrm{c}=62 \%, \mathbf{7 d}=47 \%$; i.i. $8, \mathrm{TPTU}, \mathrm{Et}_{3} \mathrm{~N}, \mathrm{DMF}, \mathrm{rt}, \mathrm{o} / \mathrm{n}$; ii. $7, \mathrm{Et}_{3} \mathrm{~N}, \mathrm{DMF}$, $\mathrm{o} / \mathrm{n}, \mathbf{4 a}=61 \%, \mathbf{4 b}=56 \%, \mathbf{4 c}=50 \%, 4 d=53 \%$.

\subsubsection{Assembly of CID MTX-Cmpd2.2}

With components $\mathbf{3 a}$ and $\mathbf{4 b}$ in hand, coupling via the Hüisgen 1,3-dipolar cycloaddition reaction (an example of a click reaction [32-35]) using copper(II) sulphate and sodium ascorbate was attempted (Scheme 3). Despite achieving the required transformation under these reaction conditions, problems were initially encountered in isolating the required tert-butyl-protected CID in a pure form, given its high molecular weight and polarity. After extensive optimisation of the purification procedure, ${ }^{t}$ Bu-MTX-Cmpd2.2 was purified using column chromatography on normal phase silica gel eluting with a mixture of $\mathrm{DCM}, \mathrm{MeOH}$ and an aqueous $\mathrm{NH}_{4} \mathrm{OH}$ solution. Subsequent treatment of ${ }^{t}$ Bu-MTX-Cmpd2.2 with TFA in the presence of thioanisole provided MTX-Cmpd2.2 (Scheme 3).

Scheme 3. Hüisgen 1,3-dipolar cycloaddition and deprotection to MTX-Cmpd2.2.

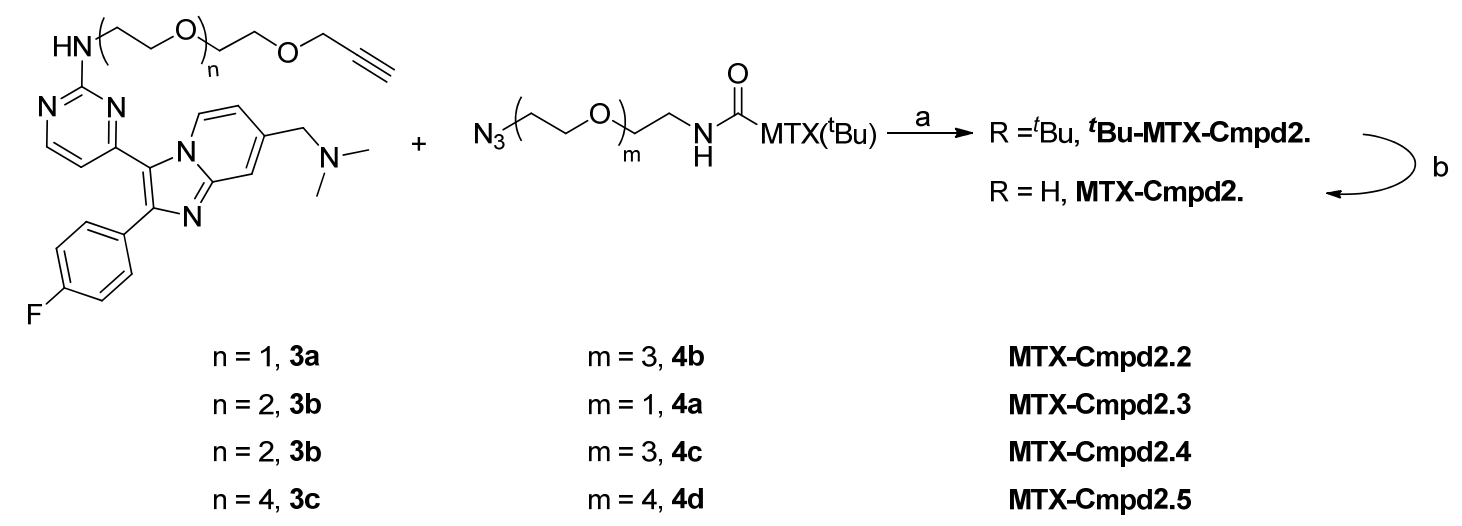




\subsubsection{Y3H results with CIDs MTX-Cmpd2.1 and MTX-Cmpd2.2}

The biological activity of MTX-Cmpd2.1 and MTX-Cmpd2.2 were assessed using our standard Y3H growth assays with yeast expressing $T$. gondii calcium-dependent protein kinase1 (TgCDPK1) fused to the activation domain. TgCDPK1 has previously been identified as a target of compound 2 [9,28]. Empty vector (the AD vector without TgCDPK1 and containing a stop codon immediately downstream of the multiple cloning site) was used as a negative control. Gratifyingly, both CIDs showed a robust $\mathrm{Y} 3 \mathrm{H}$ interaction with TgCDPK1 based on LEU2 reporter activation in 48 hour growth assays (Figure 4A), consistent with the view that the $\mathrm{Y} 3 \mathrm{H}$ system can tolerate incorporation of a 1,2,3-triazole ring in the linker unit. Interestingly, at longer time points MTX-Cmpd2.2 showed less background growth in the empty vector control than MTX-Cmpd2.1 (Figure 4B), suggesting that the use of the triazole-containing CID MTX-Cmpd2.2 may lead to a reduction in the number of false positive hits associated with a $\mathrm{Y} 3 \mathrm{H}$ screen by decreasing the background growth of yeast expressing non-interacting targets.

Figure 4. Comparison of the interaction of MTX-Cmpd2.1 and MTX-Cmpd2.2 with a known kinase target of compound 2. LEU2 reporter activation growth assay with yeast expressing a TgCDPK1-AD fusion protein in the presence of MTX-Cmpd2.1 and MTX-Cpmd2.2. Growth was assessed at (A) 48 hour and (B) 96 hour by measuring the $\mathrm{OD}_{600}$ of the yeast culture. Samples treated with the DMSO vehicle were used as negative controls. Mean values \pm SD are shown $(n=3)$.

(A)

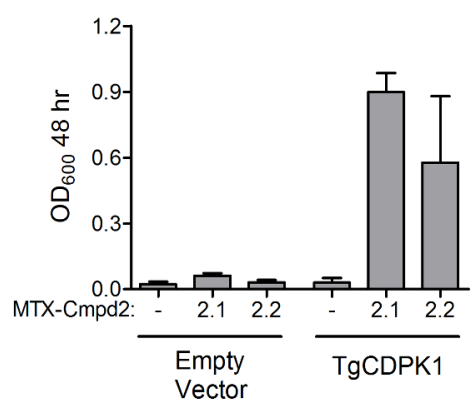

(B)

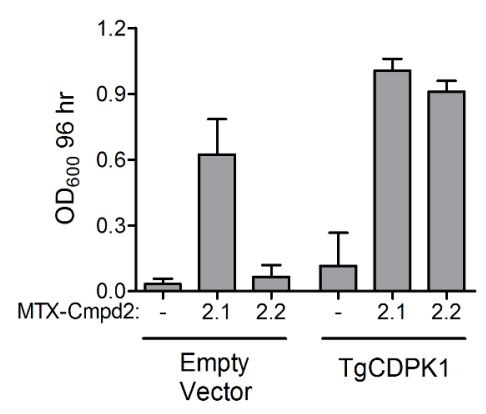

Given the observation that incorporation of a triazole ring in the linker unit was tolerated and to test the modular nature of our approach, it was decided to try and further optimise the interaction between MTX and the DHFR-DBD fusion protein and compound 2 and the TgCDPK1-AD fusion protein by preparing CIDs with: (i) an alternative positioning of the triazole ring and (ii) a modified linker length. The synthesis of MTX-Cmpd2.3-2.5 was achieved rapidly by mixing and matching the components 3 and 4 that contained varying numbers of PEG units ( $n$ and $m$ respectively) that had been prepared separately in gram quantities (Scheme 3).

\subsection{Synthesis and Analysis of Additional MTX-Cmpd2 CIDs}

To determine whether the positioning of the triazole ring affected the interaction of the CID with its target protein, MTX-Cmpd2.3 was rapidly prepared by the reaction of $\mathbf{3 b}$ and $\mathbf{4 a}$ (Schemes 2 and 3). MTX-Cmpd2.3 was then compared to MTX-Cmpd2.2 and MTX-Cmpd2.1 in the Y3H system 
by evaluating the activation of the reporter genes LEU2 (growth assay; Figure 5A) and LacZ ( $\beta$-galactosidase assay; Figure 5B). The two triazole-containing CIDs behaved similarly in both assays (compare MTX-Cmpd2.2 and MTX-Cmpd2.3 in Figure 5A and 5B), demonstrating that the position of the triazole ring has little, if any, effect on the interaction of the CID with the two fusion proteins. In the LEU2 reporter assay, the triazole-containing CIDs tended to show less growth at $48 \mathrm{~h}$ than MTX-Cmpd2.1, but all three supported similar growth at $72 \mathrm{~h}$ (Figure 5A). In the more quantitative LacZ reporter assay, the triazole-containing CIDs showed less reporter activation than MTX-Cmpd2.1, but with similar dose-response curves (Figure 5B). The triazole-containing CIDs once again showed less non-specific reporter activation with the empty vector than MTX-Cmpd2.1 (Figure 5B).

Figure 5. The effect of changing the triazole ring position in the CID linker. (A) Growth assay comparing the ability of MTX-Cmpd2.2 and MTX-Cmpd2.3 to turn on the LEU2 reporter gene in the presence of the TgCDPK1-AD fusion protein as the target. Growth was assessed at 48 and $72 \mathrm{~h}$ by measuring the $\mathrm{OD}_{600}$ of the yeast culture. Samples treated with the DMSO vehicle were used as negative controls. Mean values \pm SD are shown ( $\mathrm{n} \geq 5$ ) and were compared using paired Student's t-test. (B) $\beta$-Galactosidase assay comparing the ability of MTX-Cmpd2.1, MTX-Cmpd2.2 and MTX-Cmpd2.3 to turn on the $L a c Z$ reporter gene in the presence of TgCDPK1-AD as the target ${ }^{a}$.

(A)
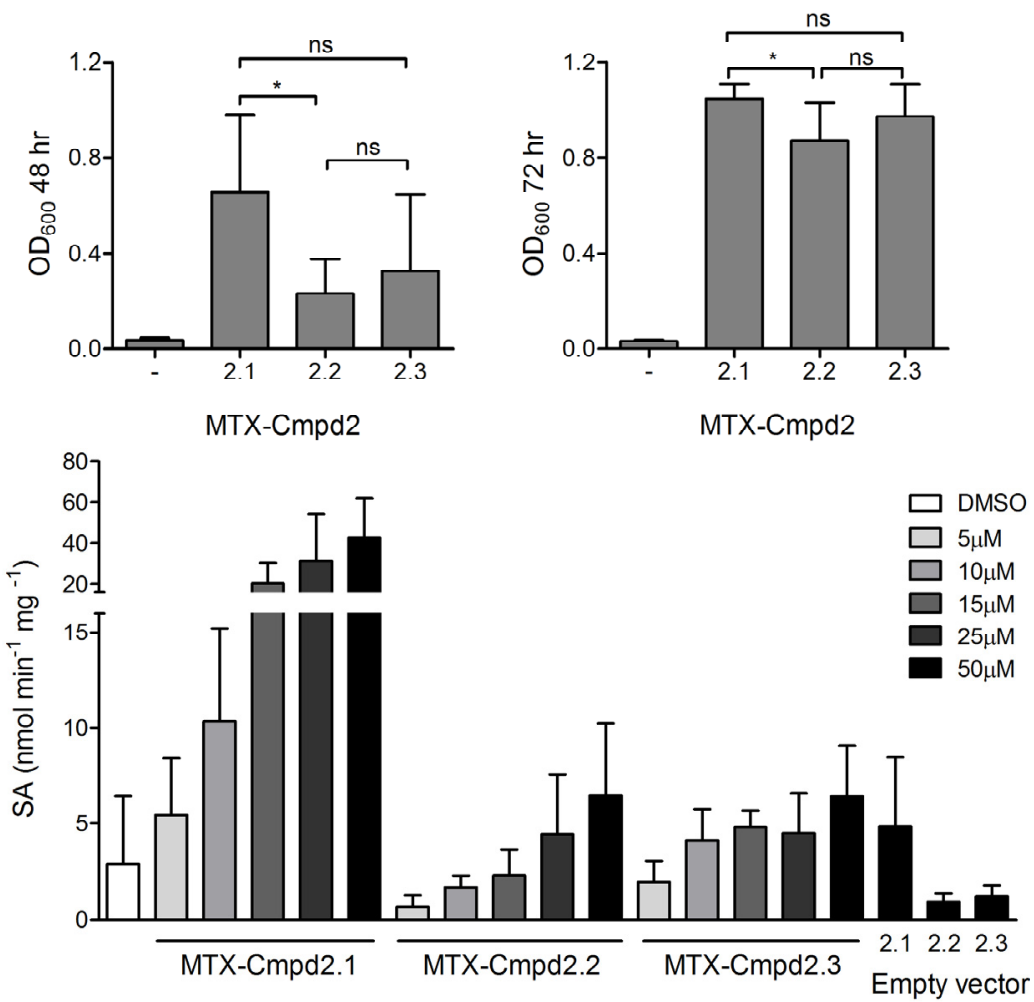

\footnotetext{
${ }^{a}$ Dose response curves of each CID are presented with the lowest dose corresponding to the vehicle (DMSO) treated samples. Mean values \pm SD are shown $(n \geq 3)$. The differences in $\beta$-galactosidase activity between the DMSO-treated samples and the lowest concentrations of CID were not statistically significant. Note that in the 72h LEU2based growth assay (panel 5A), i.e., the reporter and assay conditions most similar to those used for cDNA library screening, growth in the presence of DMSO is significantly different from growth in the presence of any of the CIDs tested.
} 
With confirmation that changes in the positioning of the triazole-PEG linker unit were compatible with this Y3H assay, the influence of linker length was investigated. Two new CIDs, MTX-Cmpd2.4 and MTX-Cmpd2.5 were prepared from $\mathbf{3 b}$ and $\mathbf{4 c}$ and $\mathbf{3 c}$ and $\mathbf{4 d}$ respectively (Scheme 3). The intermediate length CID, MTX-Cmpd2.4, gave a positive $\mathrm{Y} 3 \mathrm{H}$ interaction with the TgCDPK1-AD fusion protein in the growth assay, but the longest CID of the series, MTX-Cmpd2.5, failed to support a robust $\mathrm{Y} 3 \mathrm{H}$ response; this was particularly evident after $72 \mathrm{~h}$ (Figure 6A,B). A similar result was observed in the $L a c Z$ reporter assay (Figure 6C).

Figure 6. Effect of CID linker length on the $\mathrm{Y} 3 \mathrm{H}$ interaction between compound 2-based CIDs and TgCDPK1. (A) LEU2 reporter activation growth assay with yeast expressing a TgCDPK1-AD fusion protein in the presence of the MTX-Cmpd2 CID series with different linker lengths. Samples treated with the DMSO vehicle were used as negative controls. Mean values \pm SD are shown $(n \geq 5)$ and compared using paired Student's t-test; (B) LEU2 reporter activation growth assay as in panel A using yeast expressing TgCDPK1-AD; (C) $\beta$-Galactosidase assay in the presence of the MTX-Cmpd2 CID series with different linker lengths. Dose response curves with each CID are presented with the lowest dose corresponding to the vehicle (DMSO) treated samples. Mean values \pm SD are shown $(\mathrm{n} \geq 3)$.

(A)

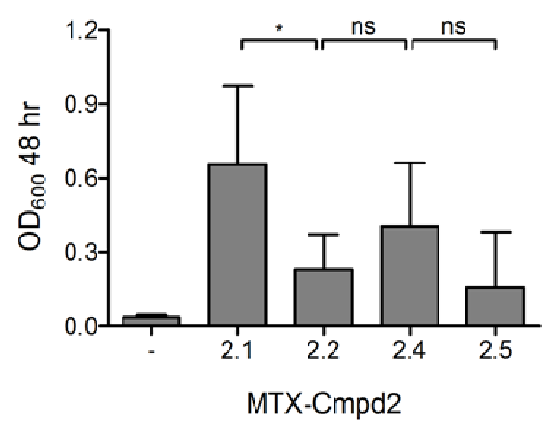

(B)

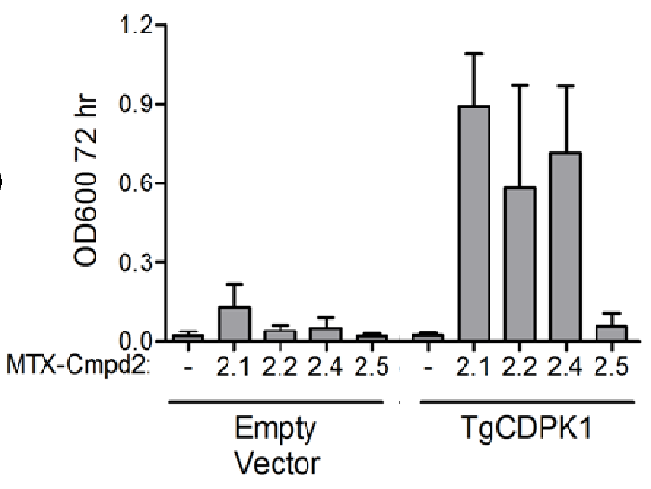

(C)

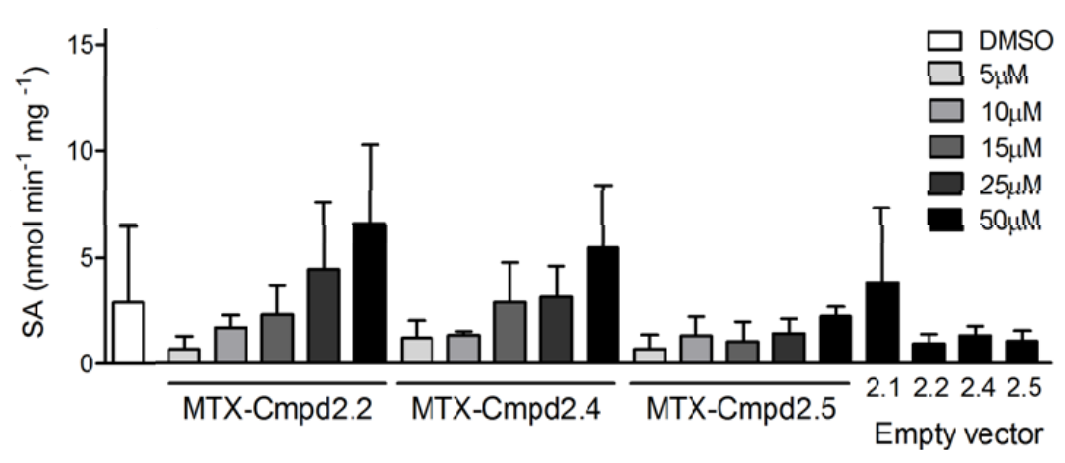

MTX-Cmpd2.4, therefore, appears to be the optimal size for the ternary complex with TgCDPK1, as this CID consistently supported slightly (though not statistically significant) better growth than MTX-Cmpd2.2 and MTX-Cmpd2.5 (Figure 6A,B). CIDs with a linker unit longer than that present in MTX-Cmpd2.4 are likely to be suboptimal because of the entropic cost that must be paid to correctly locate the two functional domains of the transcription factor. In an analogous way to the 
observations reported here for successful $\mathrm{Y} 3 \mathrm{H}$ interactions, variations in a linker unit that maintains the two domains in a fusion protein have been shown to influence significantly the appropriate separation and folding of each domain [36]. In both cases it seems likely that the separation provided by the linker unit not only allows correct folding of the two domains in the fusion protein (or the DNA binding and activation domains in the $\mathrm{Y} 3 \mathrm{H}$ system) but also affects the overall stability of the complex by changing its hydrophobicity profile [37]. Whilst small linkers restrict the conformational space of the individual domains, longer linkers may be more exposed to the solvent resulting in the inherent properties of the linker unit such as its hydrophobicity or secondary structure potentially coming into play. These could in turn affect operationally important parameters such as CID solubility, uptake or stability. It seems likely that the optimal linker length will change depending on the small molecule-protein pair being studied and therefore the ability to prepare families of CIDs relatively quickly will be important for the applications of $\mathrm{Y} 3 \mathrm{H}$ (for example in the detailed study of specific interactions between a bioactive molecule under study and a target by defining important residues in a binding site) [38-40].

\section{Experimental}

\subsection{General}

Thin layer chromatography (TLC) analysis was performed using glass plates coated with silica gel (with fluorescent indicator $\mathrm{UV}_{254}$ ). Developed plates were air dried and analysed under a UV lamp (254/365 nm). Flash chromatography was performed using silica gel (40-63 $\mu \mathrm{m}$, Fluorochem). Low resolution (LR) and high resolution (HR) electrospray mass spectral (ES-MS) analyses were acquired by electrospray ionisation (ESI), electron impact (EI) or chemical ionisation (CI). These were acquired within the School of Chemistry, University of St Andrews. Nuclear magnetic resonance (NMR) spectra were acquired at room temperature on either a Bruker Avance $300\left({ }^{1} \mathrm{H}, 300.1 \mathrm{MHz} ;{ }^{13} \mathrm{C}\right.$, $75.5 \mathrm{MHz})$, a Bruker Avance II $400\left({ }^{1} \mathrm{H}, 400.1 \mathrm{MHz} ;{ }^{13} \mathrm{C}, 100.6 \mathrm{MHz}\right)$, a Bruker Avance $500\left({ }^{1} \mathrm{H}\right.$, $\left.500 \mathrm{MHz} ;{ }^{13} \mathrm{C}, 125.7 \mathrm{MHz}\right)$ or a Bruker Avance III $500\left({ }^{1} \mathrm{H}, 500.1 \mathrm{MHz},{ }^{13} \mathrm{C}, 125.7 \mathrm{MHz}\right)$ spectrometer and in the deuterated solvent stated. All NMR spectra were acquired using the deuterated solvent as the lock. Coupling constants $(J)$ are quoted in $\mathrm{Hz}$ and are recorded to the nearest $0.1 \mathrm{~Hz}$. The following abbreviations are used; s, singlet; $d$, doublet; t, triplet; $\mathrm{m}$, multiplet and br, broad. Chemical shifts are expressed as $\delta$ in units of ppm. ${ }^{13} \mathrm{C}$-NMR spectra were recorded under the same conditions and solvents using the PENDANT sequence mode. Data processing was carried out using the TOPSPIN 2 NMR program (Bruker UK Ltd).

\subsection{Synthetic Procedures}

\subsubsection{General Procedure A: Synthesis of Compound 2-based alkyne 3}

Sulfone 5 [23] was added to a solution of aminoalkyne 6 (500 mg, 3 equiv.) in $\mathrm{CH}_{3} \mathrm{CN}(7 \mathrm{~mL})$. The reaction mixture was then irradiated in the microwave for 1 hour at $100{ }^{\circ} \mathrm{C}$ (PSI $\left.\sim 50\right)$. The reaction mixture was then concentrated in vacuo to give an oil which was purified by column chromatography (DCM/MeOH: $98 / 2$ to $95 / 5$ ). 
Compound 2-based alkyne 3a. General Procedure A was followed using aminoalkyne 6a (500 mg, $3.49 \mathrm{mmol})$ to give 3a as an amber oil (370 mg, $0.72 \mathrm{mmol}, 62 \%)$. ${ }^{1} \mathrm{H}-\mathrm{NMR}\left(400 \mathrm{MHz}, \mathrm{CDCl}_{3}\right) \delta 2.32$ (s, 6H), $2.46(\mathrm{t}, J=2.3 \mathrm{~Hz}, 1 \mathrm{H}), 3.46-3.80(\mathrm{~m}, 10 \mathrm{H}), 4.22(\mathrm{~d}, J=2.3 \mathrm{~Hz}, 2 \mathrm{H}), 5.62$ (br. s, 1H), 6.43 (d, $J=5.3 \mathrm{~Hz}, 1 \mathrm{H}), 7.00-7.16(\mathrm{~m}, 3 \mathrm{H}), 7.55(\mathrm{~s}, 1 \mathrm{H}), 7.60-7.68(\mathrm{~m}, 2 \mathrm{H}), 8.11(\mathrm{~d}, J=5.3 \mathrm{~Hz}, 1 \mathrm{H}), 9.45(\mathrm{~d}$, $J=7.3 \mathrm{~Hz}, 1 \mathrm{H}) .{ }^{13} \mathrm{C}-\mathrm{NMR}\left(126 \mathrm{MHz}, \mathrm{CDCl}_{3}\right) \delta 45.3,58.5,63.4,69.0,69.1,70.3,74.7,79.6,109.2$, 114.3, 115.7, 116.0, 118.6, 126.9, 131.2, 131.2, 138.6, 146.4, 147.7, 157.2, 157.9, 161.8, 162.4, 164.2. HRMS (ESI) calculated for $\mathrm{C}_{27} \mathrm{H}_{29} \mathrm{FN}_{6} \mathrm{O}_{2} \mathrm{Na}$ : 511.2234; found 511.2241.

Compound 2-based alkyne 3b. General Procedure A was followed using aminoalkyne $6 \mathbf{b}(500 \mathrm{mg}$, $2.67 \mathrm{mmol})$ to give $\mathbf{3 b}$ as an amber oil (295 mg, $0.55 \mathrm{mmol}, 62 \%)$. ${ }^{1} \mathrm{H}-\mathrm{NMR}\left(400 \mathrm{MHz}, \mathrm{CDCl}_{3}\right) \delta 2.34$ (s, 6H), 2.44-246 (m, 1H), $3.60-3.77(\mathrm{~m}, 14 \mathrm{H}), 4.21(\mathrm{~d}, J=2.4 \mathrm{~Hz}, 2 \mathrm{H}), 5.65(\mathrm{~m}, 1 \mathrm{H}), 6.43(\mathrm{~d}$, $J=5.3 \mathrm{~Hz}, 1 \mathrm{H}), 7.11(\mathrm{t}, J=8.7 \mathrm{~Hz}, 2 \mathrm{H}), 7.26(\mathrm{~d}, J=1.0 \mathrm{~Hz}, 1 \mathrm{H}), 7.54(\mathrm{~s}, 1 \mathrm{H}), 7.64(\mathrm{dd}, J=8.9,5.5 \mathrm{~Hz}$, $2 \mathrm{H}), 8.10(\mathrm{~d}, J=5.3 \mathrm{~Hz}, 1 \mathrm{H}), 9.44(\mathrm{~d}, J=7.3 \mathrm{~Hz}, 1 \mathrm{H}) .{ }^{13} \mathrm{C}-\mathrm{NMR}\left(126 \mathrm{MHz}, \mathrm{CDCl}_{3}\right) \delta 45.3,58.4$, 63.4, 69.1, 69.8, 70.1, 70.5, 70.6, 74.6, 77.0, 109.8, 114.3, 115.5, 115.7, 117.9, 126.9, 131.2, 131.2, 138.5, 146.4, 147.6, 157.4, 157.9, 161.8, 162.1, 164.3. HRMS (ESI) calculated for $\mathrm{C}_{29} \mathrm{H}_{33} \mathrm{FN}_{6} \mathrm{O}_{3} \mathrm{Na}$ : 555.2496; found 555.2499.

Compound 2-based alkyne 3c. General Procedure A was followed using aminoalkyne 6c (500 mg, 1.81 $\mathrm{mmol})$ to give $\mathbf{3 c}$ as an amber oil $(225 \mathrm{mg}, 0.362 \mathrm{mmol}, 60 \%) .{ }^{1} \mathrm{H}-\mathrm{NMR}\left(300 \mathrm{MHz}, \mathrm{CDCl}_{3}\right) \delta 2.23$ (s, 6H), 2.44-2.46 (m, 1H), 3.48-3.94 (m, 22H), 4.18-4.20 (m, 2H), $5.75(\mathrm{t}, J=5.0 \mathrm{~Hz}, 1 \mathrm{H}), 6.37(\mathrm{~d}$, $J=5.3 \mathrm{~Hz}, 1 \mathrm{H}), 6.93-7.18(\mathrm{~m}, 3 \mathrm{H}), 7.49-7.69(\mathrm{~m}, 3 \mathrm{H}), 8.11(\mathrm{~d}, J=5.3 \mathrm{~Hz}, 1 \mathrm{H}), 9.45(\mathrm{~d}, J=7.2, \mathrm{~Hz}$, 1H). ${ }^{13} \mathrm{C}-\mathrm{NMR}\left(101 \mathrm{MHz}, \mathrm{CDCl}_{3}\right) \delta 45.3,58.4,63.4,69.1,69.4,70.1,70.3,70.4,70.4,70.5,70.5$, 70.6, 74.5, 79.6, 109.8, 114.2, 115.6, 116.3, 118.0, 126.9, 131.2, 131.2, 138.6, 146.4, 147.7, 157.4, 157.9, 161.8, 162.1, 164.2. HRMS (ESI) calculated for $\mathrm{C}_{33} \mathrm{H}_{41} \mathrm{FN}_{6} \mathrm{O}_{5} \mathrm{Na}$ : 643.3020, found 643.2970.

\subsubsection{General Procedure B: Synthesis of ${ }^{t}$ Bu-MTX-azide Components 4}

Dry diisopropylethylamine (2 equiv.) was added to a suspension of methotrexate (MTX) 8 [23] in anhydrous DMF under a nitrogen atmosphere. TPTU was then added to the flask and the resulting mixture left to stir at room temperature overnight. In a separate flask, diisopropylethylamine (2 equiv.) was added to a suspension of the aminoazide 7 (1.1 equiv.) in anhydrous DMF $(12 \mathrm{~mL})$ under a nitrogen atmosphere. The activated acid solution was then added to the flask via cannula and the flask rinsed with anhydrous DMF $(10 \mathrm{~mL})$. The resulting mixture was then stirred at room temperature overnight before being concentrated in vacuo to give $\mathbf{4}$ as a dark brown oil. Purification was achieved via column chromatography (DCM/MeOH: 98/2 to 9/1).

${ }^{t} B u$-MTX-Azide 4a. General Procedure B was followed using aminoazide 7a (2.0 g, 0.015 mol) to give 4a (5.17 g, $8.31 \mathrm{mmol}, 61 \%)$ as a dark orange solid. ${ }^{1} \mathrm{H}-\mathrm{NMR}(500 \mathrm{MHz}, \mathrm{DMSO}) \delta 1.40$ (s, 9H), 1.90 (m, 1H), 1.92-2.01 (m, 1H), 2.13-2.26 (m, 2H), 3.12-3.25 (m, 5H), 3.39-3.67 (m, 6H), 4.18-4.22 (m, 1H), 4.80 (s, 2H), 6.73-6.80 (br. s, 2H), 6.82-6.88 (m, 2H), 7.70-7.73 (m, 2H), 7.87-7.99 (m, 1H), $8.27(\mathrm{~d}, J=7.3 \mathrm{~Hz}, 1 \mathrm{H}), 8.59$ (s, 1H). ${ }^{13} \mathrm{C}-\mathrm{NMR}(126 \mathrm{MHz}, \mathrm{DMSO}) \delta 26.9,28.1,32.3,38.9,50.3$, 53.4, 55.3, 69.3, 69.4, 70.2, 80.7, 111.5, 121.6, 122.0, 129.3, 147.3, 149.5, 151.3, 154.8, 162.2, 163.1, 166.7, 172.0, 172.1. HRMS (ESI) calculated for $\mathrm{C}_{28} \mathrm{H}_{38} \mathrm{~N}_{12} \mathrm{O}_{5} \mathrm{Na}$ : 645.2986; found 645.2997. 
${ }^{t}$ Bu-MTX-Azide 4b. General Procedure B was followed using aminoazide 7b (2.1 g, $\left.0.012 \mathrm{~mol}\right)$ to give 4b as an orange solid (3.9 g, $5.85 \mathrm{mmol}, 56 \%)$. ${ }^{1} \mathrm{H}-\mathrm{NMR}(300 \mathrm{MHz}, \mathrm{DMSO}) \delta 1.39$ (s, 9H), 1.82-2.07 (m, 2H), 2.14-2.26 (m, 2H), 3.12-3.25 (m, 5H), 3.39-3.66 (m, 10H), 4.14-4.28 (m, 1H), $4.80(\mathrm{~s}, 2 \mathrm{H}), 6.75-6.87(\mathrm{~m}, 2 \mathrm{H}), 6.96$ (br. s, 2H), 7.68-7.78 (m, 2H), 7.86-8.07 (m, 1H), $8.27(\mathrm{~d}$, $J=7.3 \mathrm{~Hz}, 1 \mathrm{H}), 8.60$ (s, 1H). ${ }^{13} \mathrm{C}-\mathrm{NMR}(126 \mathrm{MHz}, \mathrm{DMSO}) \delta 26.9,28.1,32.3,39.0,39.6,50.4,53.4$, 55.3, 69.6, 69.7, 70.0, 80.7, 111.5, 121.6, 121.9, 129.4, 147.1, 149.5, 151.3, 162.5, 163.2, 166.8, 172.0, 172.1. HRMS (ESI) calculated for $\mathrm{C}_{30} \mathrm{H}_{42} \mathrm{~N}_{12} \mathrm{O}_{6} \mathrm{Na}$ : 689.3248; found 689.3262 .

${ }^{t}$ Bu-MTX-Azide 4c. General Procedure B was followed using aminoazide 7c (2.0 g, $\left.9.16 \mathrm{mmol}\right)$ to give 4c as a bright yellow solid (2.9 g, $4.16 \mathrm{mmol}, 50 \%) .{ }^{1} \mathrm{H}-\mathrm{NMR}(300 \mathrm{MHz}, \mathrm{DMSO}) \delta 1.39$ (s, 9H), $1.81-2.12(\mathrm{~m}, 2 \mathrm{H}), 2.18-2.22(\mathrm{~m}, 2 \mathrm{H}), 3.11-3.24(\mathrm{~m}, 5 \mathrm{H}), 3.34-3.66(\mathrm{~m}, 14 \mathrm{H}), 4.18-4.21(\mathrm{~m}, 1 \mathrm{H})$, $4.78(\mathrm{~s}, 2 \mathrm{H}), 6.61(\mathrm{~s}, 2 \mathrm{H}), 6.77-6.86(\mathrm{~m}, 2 \mathrm{H}), 7.62-7.77(\mathrm{~m}, 2 \mathrm{H}), 7.90(\mathrm{t}, J=5.5 \mathrm{~Hz}, 1 \mathrm{H}), 8.25(\mathrm{~d}$, $J=7.3 \mathrm{~Hz}, 1 \mathrm{H}), 8.56$ (s, 1H). ${ }^{13} \mathrm{C}-\mathrm{NMR}(126 \mathrm{MHz}, \mathrm{DMSO}) \delta 26.9,28.1,32.3,39.0,39.4,50.4,53.4$, $55.3,69.5,69.7,70.0,70.1,70.2,70.2,80.7,111.5,121.6,122.1,129.4,147.9,149.5,151.3,153.0$, 161.4, 163.1, 166.7, 172.0, 172.1. HRMS (ESI) calculated for $\mathrm{C}_{32} \mathrm{H}_{46} \mathrm{~N}_{12} \mathrm{O}_{7} \mathrm{Na}$ : 733.3510; found 733.3515.

${ }^{t} B u$-MTX-Azide 4d. General Procedure B was followed using aminoazide 7d (2.1 g, $\left.8.00 \mathrm{mmol}\right)$ to give 4d as an orange solid (3.2 g, $4.24 \mathrm{mmol}, 53 \%)$. ${ }^{1} \mathrm{H}-\mathrm{NMR}(500 \mathrm{MHz}, \mathrm{DMSO}) \delta 1.39$ (s, 9H), 1.80-2.07 (m, 2H), 2.15-2.24 (m, 2H), 3.10-3.19 (m, 5H), 3.32-3.69 (m, 18H), 4.18-4.21 (m, 1H), 4.78 (s, 2H), 6.65 (br. s, 2H), 6.81 (d, $J=8.6 \mathrm{~Hz}, 2 \mathrm{H}), 7.48$ (br. s, 2H), 7.72 (d, $J=8.7 \mathrm{~Hz}, 2 \mathrm{H}$ ), $7.88-7.94(\mathrm{~m}, 1 \mathrm{H}), 8.25(\mathrm{~d}, J=7.3 \mathrm{~Hz}, 1 \mathrm{H}), 8.56(\mathrm{~s}, 1 \mathrm{H}) .{ }^{13} \mathrm{C}-\mathrm{NMR}(126 \mathrm{MHz}, \mathrm{DMSO}) \delta 26.4,27.6$, $31.7,38.5,49.9,52.9,54.8,69.0,69.2,69.5,69.6,69.7,69.7,69.7,80.2,110.9,121.0,121.4,128.8$, 146.0, 149.1, 150.8, 155.0, 162.6, 162.7, 166.2, 171.5, 171.5. HRMS (ESI) calculated for $\mathrm{C}_{34} \mathrm{H}_{50} \mathrm{~N}_{12} \mathrm{O}_{8} \mathrm{Na}$ : 777.3772 ; found 777.3767 .

\subsubsection{General Procedure C: Coupling of $\mathbf{3}$ and $\mathbf{4}$}

Compound 2 based alkyne 3 (1.1 equiv.) was dissolved in a mixture of ${ }^{t} \mathrm{BuOH} / \mathrm{H}_{2} \mathrm{O}(1 / 2)$. The ${ }^{t} \mathrm{Bu}-\mathrm{MTX}$-azide 4 was then added to the flask and the resulting mixture left to stir vigorously at room temperature until complete dissolution of both starting materials had occurred ( $c$ a. $30 \mathrm{~min}$ ). Copper (II) sulphate pentahydrate (1.4 equiv.) was then added to the flask followed by sodium ascorbate (2.8 equiv.). The reaction mixture was then left to stir at room temperature for $24 \mathrm{~h}$. At that time, an additional 1.4 equiv. of copper (II) sulphate pentahydrate were added to the flask followed once again by sodium ascorbate ( 2.8 equiv.). The reaction mixture was left to stir at room temperature for an

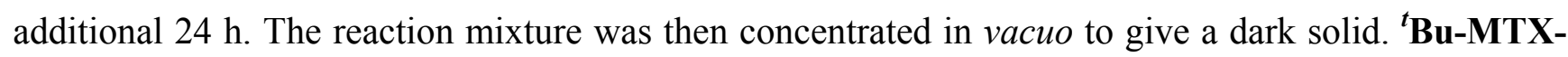
Cpmd2.2-2.5 was successfully isolated following column chromatography (DMC/MeOH/aq. $\mathrm{NH}_{4} \mathrm{OH}$ : $100 / 1 / 6$ drops to $9 / 1 / 6$ drops).

${ }^{t}$ Bu-MTX-Cpmd2.2. General Procedure $\mathrm{C}$ was followed using 3a (187 mg, $0.38 \mathrm{mmol}, 1.1$ equiv.) and 4b (232 mg, $0.35 \mathrm{mmol})$ to give ${ }^{t} \mathbf{B u}-\mathbf{M T X}-\mathbf{C p m d 2 . 2}$ as a film $(100 \mathrm{mg}, 0.087 \mathrm{mmol}, 25 \%) .{ }^{1} \mathrm{H}$ NMR (500 MHz, DMSO) $\delta 1.38(\mathrm{~s}, 9 \mathrm{H}), 1.86-1.88(\mathrm{~m}, 1 \mathrm{H}), 1.98-2.03(\mathrm{~m}, 1 \mathrm{H}), 2.19-2.27(\mathrm{~m}, 2 \mathrm{H})$, $2.98(\mathrm{~s}, 3 \mathrm{H}), 3.15-3.80(\mathrm{~m}, 29 \mathrm{H}), 4.15-4.25(\mathrm{~m}, 1 \mathrm{H}), 4.48-4.63(\mathrm{~m}, 4 \mathrm{H}), 4.80(\mathrm{~s}, 2 \mathrm{H}), 6.30-6.40(\mathrm{~m}$, $1 \mathrm{H}), 6.81(\mathrm{~d}, J=6.7 \mathrm{~Hz}, 2 \mathrm{H}), 6.88-6.91(\mathrm{~m}, 1 \mathrm{H}), 7.11-7.20(\mathrm{~m}, 1 \mathrm{H}), 7.30(\mathrm{t}, J=8.7 \mathrm{~Hz}, 2 \mathrm{H})$, 
$7.62-7.78(\mathrm{~m}, 4 \mathrm{H}), 7.81(\mathrm{~s}, 1 \mathrm{H}) .7 .90-7.92(\mathrm{~m}, 1 \mathrm{H}), 8.03(\mathrm{~s}, 1 \mathrm{H}), 8.18(\mathrm{~d}, J=5.2 \mathrm{~Hz}, 1 \mathrm{H}), 8.26(\mathrm{~d}, J=$ $7.2 \mathrm{~Hz}, 1 \mathrm{H}), 8.59$ (s, 1H). ${ }^{13} \mathrm{C}-\mathrm{NMR}(126 \mathrm{MHz}, \mathrm{DMSO}) \delta 26.4,27.6,31.7,38.4,39.5,39.9,39.9,40.0$, $40.5,42.7,49.2,52.9,54.8,63.4,68.6,68.9,69.0,69.3,69.4,69.6,80.2,109,1,110.9,114.7,115.4$, 115.6, 119.0, 121.1, 121.6, 124.2, 128.8, 131.1, 131.7, 143.7, 147.3, 147.4, 148.6, 149.0, 150.8, 159.0, 161.3, 161.4, 162.6, 163.6, 166.2, 171.5, 171.5, 171.9. HRMS (ESI) calculated for $\mathrm{C}_{57} \mathrm{H}_{71} \mathrm{FN}_{18} \mathrm{O}_{8} \mathrm{Na}$ : 1177.5584; found 1177.5598.

${ }^{t}$ Bu-MTX-Cpmd2.3. General Procedure $\mathrm{C}$ was followed using 3b (195 mg, $0.37 \mathrm{mmol}$, 1.1 equiv.) and $4 \mathbf{a}(207 \mathrm{mg}, 0.33 \mathrm{mmol})$ to give ${ }^{\boldsymbol{t}} \mathbf{B u}-\mathbf{M T X}-\mathbf{C p m d 2 . 3}$ as a film (97 mg, $\left.0.084 \mathrm{mmol}, 25 \%\right) .{ }^{1} \mathrm{H}$ NMR (300 MHz, DMSO) $\delta 1.37(\mathrm{~s}, 9 \mathrm{H}), 1.80-1.88(\mathrm{~m}, 1 \mathrm{H}), 1.90-1.97(\mathrm{~m}, 1 \mathrm{H}), 2.15-2.20(\mathrm{~m}, 2 \mathrm{H})$, $3.06-3.23(\mathrm{~m}, 6 \mathrm{H}), 3.36-3.65(\mathrm{~m}, 25 \mathrm{H}), 4.18-4.21(\mathrm{~m}, 1 \mathrm{H}), 4.46-4.50(\mathrm{~m}, 4 \mathrm{H}), 4.77(\mathrm{~s}, 2 \mathrm{H})$, 6.29-6.32 (m, 1H), 6.67 (br. s, 2H), $6.80(\mathrm{~m}, 2 \mathrm{H}), 7.05(\mathrm{~d}, J=7.1 \mathrm{~Hz}, 1 \mathrm{H}), 7.28(\mathrm{t}, J=8.8 \mathrm{~Hz}, 2 \mathrm{H})$, $7.58-7.75(\mathrm{~m}, 5 \mathrm{H}), 7.86(\mathrm{t}, J=5.7 \mathrm{~Hz}, 1 \mathrm{H}), 8.02(\mathrm{~s}, 1 \mathrm{H}), 8.16-8.18(\mathrm{~m}, 1 \mathrm{H}), 8.24-8.26(\mathrm{~m}, 1 \mathrm{H}), 8.55$ (s, 1H). ${ }^{13} \mathrm{C}-\mathrm{NMR}(126 \mathrm{MHz}, \mathrm{DMSO}) \delta 26.4,27.6,31.7,38.4,38.4,39.4,39.9,39.9,40.0,43.1,49.2$, 52.9, 54.8, 63.4, 68.6, 68.8, 69.2, 69.5, 69.6, 80.2, 111.1, 114.7, 115.4, 115.6, 119.0, 121.1, 121.5, 124.2, 128.8, 131.1, 131.6, 143.7, 147.9, 148.6, 149.1, 150.8, 159.1, 161.1, 162.1, 162.7, 163.6, 166.2, 171.5, 171.5, 171.9. HRMS (ESI) calculated for $\mathrm{C}_{57} \mathrm{H}_{71} \mathrm{FN}_{18} \mathrm{O}_{8} \mathrm{Na}$ : 1177.5584; found 1177.5742.

${ }^{t}$ Bu-MTX-Cpmd2.4. General Procedure $\mathrm{C}$ was followed using 3b (220 mg, $0.41 \mathrm{mmol}$, 1.1 equiv.) and $4 \mathbf{c}(267 \mathrm{mg}, 0.37 \mathrm{mmol})$ to give ${ }^{t}$ Bu-MTX-Cpmd2.4 as a film $(130 \mathrm{mg}, 0.104 \mathrm{mmol}, 28 \%) .{ }^{1} \mathrm{H}$ NMR (500 MHz, DMSO) $\delta 1.38(\mathrm{~s}, 9 \mathrm{H}), 1.82-1.89(\mathrm{~m}, 1 \mathrm{H}), 1.99-2.02$ (m, 1H), 2.19 (m, 2H), 2.10$3.19(\mathrm{~m}, 5 \mathrm{H}), 3.33-3.61(\mathrm{~m}, 32 \mathrm{H}), 3.78(\mathrm{dt}, J=9.6,5.6 \mathrm{~Hz}, 2 \mathrm{H}), 4.19-4.21(\mathrm{~m}, 1 \mathrm{H}), 4.49-4.51$ (m, $4 \mathrm{H}), 4.79(\mathrm{~s}, 2 \mathrm{H}), 6.30-6.34(\mathrm{~m}, 1 \mathrm{H}), 6.59-6.62(\mathrm{~m}, 1 \mathrm{H}), 6.78-6.87(\mathrm{~m}, 2 \mathrm{H}), 7.11(\mathrm{~d}, J=7.5 \mathrm{~Hz}, 1 \mathrm{H})$, $7.30(\mathrm{t}, J=8.6 \mathrm{~Hz}, 2 \mathrm{H}), 7.52(\mathrm{~s}, 1 \mathrm{H}), 7.69-7.81(\mathrm{~m}, 4 \mathrm{H}), 7.91(\mathrm{t}, J=5.8 \mathrm{~Hz}, 1 \mathrm{H}), 8.04(\mathrm{~s}, 1 \mathrm{H}), 8.18(\mathrm{~d}$, $J=5.2 \mathrm{~Hz}, 1 \mathrm{H}), 8.23-8.29(\mathrm{~m}, 1 \mathrm{H}), 8.58(\mathrm{~s}, 1 \mathrm{H}) .{ }^{13} \mathrm{C}-\mathrm{NMR}(126 \mathrm{MHz}, \mathrm{DMSO}) \delta 26.4,27.6,31.7$, $38.5,39.5,39.9,40.0,40.1,43.0,49.2,52.9,54.8,59.7,63.4,68.6,68.9,69.0,69.5,69.5,69.6,69.6$, $69.7,80.2,111.0,114.7,115.4,115.6,118.9,119.0,121.1,121.5,124.2,128.8,131.1,131.7,143.7$, $146.3,148.6,149.0,150.8,159.0,161.4,162.6,163.6,166.2,171.5,171.5,171.9$. HRMS (ESI) calculated $\mathrm{C}_{61} \mathrm{H}_{80} \mathrm{FN}_{18} \mathrm{O}_{10} 1243.6289$ found 1243.6310 .

${ }^{t}$ Bu-MTX-Cpmd2.5. General Procedure $\mathrm{C}$ was followed using 3d (217 mg, $0.35 \mathrm{mmol}, 1.1$ equiv.) and 4d (220 mg, $0.29 \mathrm{mmol})$ to give ${ }^{t} \mathbf{B u}-\mathbf{M T X}-\mathbf{C p m d 2 . 5}$ as a film (92 mg, $\left.0.067 \mathrm{mmol}, 21 \%\right) .{ }^{1} \mathrm{H}$ NMR (500 MHz, DMSO) $\delta 1.38(\mathrm{~s}, 9 \mathrm{H}), 1.83-2.03(\mathrm{~m}, 2 \mathrm{H}), 2.18-2.21(\mathrm{~m}, 2 \mathrm{H}), 3.12-3.23(\mathrm{~m}, 5 \mathrm{H})$, 3.29-3.61 (m, 42H), 3.78-3.81 (m, 2H), 4.16-4.27 (m, 1H), 4.48-4.51 (m, 4H), $4.77(\mathrm{~s}, 2 \mathrm{H})$, 6.32-6.35 (m, 1H), 6.66 (br. s, 2H), 6.80-6.82 (m, 2H), 7.03-7.05 (m, 1H), 7.28 (t, J=8.8 Hz, 2H), $7.43(\mathrm{~s}, 1 \mathrm{H}), 7.56(\mathrm{~s}, 1 \mathrm{H}), 7.61-7.74(\mathrm{~m}, 4 \mathrm{H}), 7.89(\mathrm{t}, J=5.7 \mathrm{~Hz}, 1 \mathrm{H}), 8.03(\mathrm{~s}, 1 \mathrm{H}), 8.15(\mathrm{~d}, J=5.2 \mathrm{~Hz}$, $1 \mathrm{H}), 8.24(\mathrm{~d}, J=7.2 \mathrm{~Hz}, 1 \mathrm{H}), 8.55(\mathrm{~s}, 1 \mathrm{H}) .{ }^{13} \mathrm{C}-\mathrm{NMR}(126 \mathrm{MHz}, \mathrm{DMSO}) \delta 26.4,27.6,31.7,38.5$, 39.4, 39.9, 39.9, 40.0, 40.5, 43.7, 49.2, 52.9, 54.8, 57.4, 60.1, 60.3, 63.4, 66.3, 68.4, 68.6, 68.9, 69.0, $69.4,69.5,69.5,69.6,69.7,72.3,77.1,80.2,111.0,114.7,115.4,115.6,119.0,121.0,121.5,124.2$, $128.8,131.1,131.6,143.7,146.2,148.1,149.1,150.8,162.6,166.2,171.5,171.5$. HRMS (ESI) calculated $\mathrm{C}_{67} \mathrm{H}_{91} \mathrm{FN}_{18} \mathrm{O}_{13} \mathrm{Na} 1397.6895$ found 1397.6901 . 


\subsubsection{General Procedure D: Boc Deprotection of ${ }^{t}$ Bu-MTX-Cmpd2}

Thioanisole $(30 \mu \mathrm{L})$ was added to a solution of ${ }^{t} \mathbf{B u}$-MTX-Cmpd2 followed by TFA $(30 \mu \mathrm{L})$. The resulting mixture was then stirred at room temperature overnight before being concentrated in vacuo to give a brown solid. This was then suspended in cyclohexane to remove any traces of thioanisole and the resulting mixture concentrated in vacuo to give a yellow/pale orange film.

MTX-Cpmd2.2. General Procedure D was followed using ${ }^{t}$ Bu-MTX-Cpmd2.2 (90 mg, 0.090 mmol) to give MTX-Cpmd2.2 as a yellow amorphous solid (84 mg, $0.076 \mathrm{mmol}, 85 \%)$. ${ }^{1} \mathrm{H}-\mathrm{NMR}$ (500 MHz, DMSO) $\delta 1.89-2.10(\mathrm{~m}, 2 \mathrm{H}), 2.14-2.23(\mathrm{~m}, 2 \mathrm{H}), 2.82(\mathrm{~s}, 6 \mathrm{H}), 3.05-3.62(\mathrm{~m}, 19 \mathrm{H}), 3.71-3.82$ (m, 2H), 4.28-4.32 (m, 1H), 4.42-4.52 (m, 6H), $4.87(\mathrm{~s}, 2 \mathrm{H}), 6.32-6.42(\mathrm{~m}, 1 \mathrm{H}), 6.81(\mathrm{~d}, J=8.3 \mathrm{~Hz}$, 2H), $7.06(\mathrm{~s}, 1 \mathrm{H}), 7.14-7.36(\mathrm{~m}, 4 \mathrm{H}), 7.60-7.76(\mathrm{~m}, 4 \mathrm{H}), 7.91(\mathrm{~d}, J=6.2 \mathrm{~Hz}, 1 \mathrm{H}), 8.04-8.08(\mathrm{~m}, 1 \mathrm{H})$, $8.17-8.21(\mathrm{~m}, 1 \mathrm{H}), 8.31(\mathrm{~d}, J=7.4 \mathrm{~Hz}, 1 \mathrm{H}), 8.71(\mathrm{~s}, 1 \mathrm{H}), 9.08$ (s, 1H), 9.29 (s, 1H). ${ }^{13} \mathrm{C}-\mathrm{NMR}(126 \mathrm{MHz}$, DMSO) $\delta$ 26.5, 31.9, 38.4, 39.8, 40.6, 49.2, 52.2, 54.7, 58.4, 60.7, 63.4, 68.6, 69.3, 69.4, 69.6, 69.7, $70.4,72.3,108.8,111.1,115.6,115.7,116.1,119.4,120.1,121.7,122.1,124.2,124.7,125.8,129.2$, $129.9,130.6,131.3,138.7,143.7,144.2,145.2,145.6,148.7,149.2,150.6,151.1,155.8,157.3,161.4$, 163.7, 166.1, 171.7, 173.8. HRMS (ESI) calculated for $\mathrm{C}_{53} \mathrm{H}_{64} \mathrm{FN}_{18} \mathrm{O}_{8}$ : 1099.5139; found 1099.5127.

MTX-Cpmd2.3. General Procedure D was followed using ${ }^{\boldsymbol{t}} \mathbf{B u}-\mathbf{M T X}-\mathbf{C p m d 2 . 3}$ (35 $\mathrm{mg}, 0.030 \mathrm{mmol}$ ) to give MTX-Cpmd2.3 as a dark orange amorphous solid (24 mg, $0.023 \mathrm{mmol}, 76 \%$ ). ${ }^{1} \mathrm{H}-\mathrm{NMR}$ (400 MHz, DMSO) $\delta 1.85-2.06(\mathrm{~m}, 2 \mathrm{H}), 2.18-2.22(\mathrm{~m}, 2 \mathrm{H}), 2.85(\mathrm{~s}, 6 \mathrm{H}), 3.20-3.79(\mathrm{~m}, 21 \mathrm{H}), 4.33-4.42$ $(\mathrm{m}, 1 \mathrm{H}), 4.43-4.55(\mathrm{~m}, 6 \mathrm{H}), 4.90(\mathrm{~s}, 2 \mathrm{H}), 6.31-6.41(\mathrm{~m}, 1 \mathrm{H}), 6.86(\mathrm{~d}, J=9.1 \mathrm{~Hz}, 2 \mathrm{H}), 7.11-7.22(\mathrm{~m}$, 1H), 7.24-7.39 (m, 4H), 7.66-7.81 (m, 4H), 7.88-7.95 (m, 1H), $8.06(\mathrm{~d}, J=7.2 \mathrm{~Hz}, 1 \mathrm{H}), 8.24(\mathrm{~d}$, $J=5.3 \mathrm{~Hz}, 1 \mathrm{H}), 8.34(\mathrm{~d}, J=7.2 \mathrm{~Hz}, 1 \mathrm{H}), 8.74(\mathrm{~s}, 1 \mathrm{H}), 9.10(\mathrm{~s}, 1 \mathrm{H}), 9.30(\mathrm{~s}, 1 \mathrm{H}) .{ }^{13} \mathrm{C}-\mathrm{NMR}(126 \mathrm{MHz}$, DMSO) $\delta 26.5,31.9,38.4,39.4,40.1,49.7,52.7,55.3,58.6,60.6,63.9,68.5,69.4,69.6,69.8,70.1$, $108.8,111.6,115.5,115.6,116.10,119.7,120.5,121.7,122.2,124.7,125.2,129.4,130.9,131.2$, $138.5,143.7,144.2,145.3,148.7,149.1,150.6,151.2,155.8,157.3,161.3,162.9,163.1,166.1,166.6$, 171.8, 173.9. HRMS (ESI) calculated for $\mathrm{C}_{53} \mathrm{H}_{63} \mathrm{FN}_{18} \mathrm{O}_{8} \mathrm{Na}$ : 1121.4958; found 1121.4946.

MTX-Cpmd2.4. General Procedure D was followed using ${ }^{\boldsymbol{t}}$ Bu-MTX-Cpmd2.4 (90 mg, $0.070 \mathrm{mmol}$ ) to give MTX-Cpmd2.4 as a yellow/orange amorphous solid (56 mg, $0.045 \mathrm{mmol}, 65 \%){ }^{1} \mathrm{H}-\mathrm{NMR}$ (500 MHz, DMSO) $\delta 1.89-2.10(\mathrm{~m}, 2 \mathrm{H}), 2.18-2.25(\mathrm{~m}, 2 \mathrm{H}), 3.16-3.66(\mathrm{~m}, 37 \mathrm{H}), 4.25-4.32(\mathrm{~m}, 1 \mathrm{H})$, $4.36-4.58(\mathrm{~m}, 6 \mathrm{H}), 4.87(\mathrm{~s}, 2 \mathrm{H}), 6.31-6.42(\mathrm{~m}, 1 \mathrm{H}), 6.76-6.89(\mathrm{~m}, 2 \mathrm{H}), 7.07-7.41(\mathrm{~m}, 5 \mathrm{H}), 7.60-7.84$ (m, 4H), 7.90-7.92 (m, 1H), $8.03(\mathrm{~d}, J=10.5 \mathrm{~Hz}, 1 \mathrm{H}), 8.20(\mathrm{~d}, J=5.5 \mathrm{~Hz}, 1 \mathrm{H}), 8.30(\mathrm{~d}, J=7.3 \mathrm{~Hz}$, 1H), $8.71(\mathrm{~s}, 1 \mathrm{H}), 9.07(\mathrm{~s}, 1 \mathrm{H}), 9.28(\mathrm{~s}, 1 \mathrm{H}) .{ }^{13} \mathrm{C}-\mathrm{NMR}(126 \mathrm{MHz}, \mathrm{DMSO}) \delta 26.5,31.9,38.5,39.0$, 39.2, 40.1, 42.0, 49.2, 52.2, 54.8, 58.9, 63.4, 68.6, 68.9, 69.0, 69.5, 69.5, 69.6, 69.6, 69.7, 108.8, 111.1, $115.5,115.7,120.0,121.4,121.6,122.6,124.2$, 124.7, 125.9, 126.5, 128.9, 129.5, 131.2, 138.0, 138.6, 143.7, 145.9, 148.7, 149.1, 150.6, 151.1, 161.4, 162.6, 166.1, 171.7, 173.7. HRMS (ESI) calculated for $\mathrm{C}_{57} \mathrm{H}_{72} \mathrm{FN}_{18} \mathrm{O}_{10}$ : 1187.5663 ; found 1187.5654 .

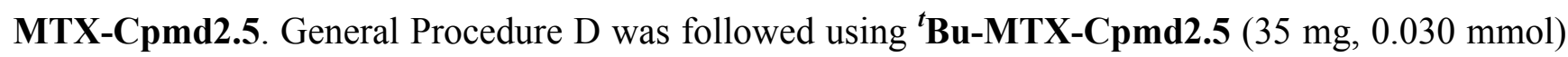
to give MTX-Cpmd2.5 as an dark orange amorphous solid (28 mg, $0.021 \mathrm{mmol}, 69 \%)$. ${ }^{1} \mathrm{H}-\mathrm{NMR}$ (300 MHz, DMSO) $\delta$ 1.82-2.26 (m, 6H), $2.82(\mathrm{~s}, 6 \mathrm{H}), 3.21-3.85(\mathrm{~m}, 41 \mathrm{H}), 4.18-4.21(\mathrm{~m}, 1 \mathrm{H})$, 
4.33-4.59 (m, 6H), $4.88(\mathrm{~s}, 2 \mathrm{H}), 6.32-6.42(\mathrm{~m}, 1 \mathrm{H}), 6.82(\mathrm{~d}, J=8.6 \mathrm{~Hz}, 2 \mathrm{H}), 7.07-7.37(\mathrm{~m}, 5 \mathrm{H})$, 7.59-7.79 (m, 4H), 7.88-7.92 (m, 1H), $8.04(\mathrm{~d}, J=3.0 \mathrm{~Hz}, 1 \mathrm{H}), 8.18-8.21(\mathrm{~m}, 1 \mathrm{H}), 8.31(\mathrm{~d}, J=7.2 \mathrm{~Hz}$, 1H), $8.71(\mathrm{~s}, 1 \mathrm{H}), 9.10(\mathrm{~s}, 1 \mathrm{H}), 9.29(\mathrm{~s}, 1 \mathrm{H}) .{ }^{13} \mathrm{C}-\mathrm{NMR}(126 \mathrm{MHz}, \mathrm{DMSO}) \delta 27.0,32.4,38.99,39.1$, 39.4, 40.2, 42.4, 49.7, 52.7, 55.2, 57.7, 60.6, 63.9, 68.9, 69.1, 69.4, 69.5, 69.9, 70.0, 70.1, 70.2, 70.3, $72.8,80.8102 .0,108.8,109.7,111.6,115.8,116.0,120.2,121.8,122.4,124.3,124.7,125.8,129.4$, 131.5, 138.2, 144.2, 146.2, 148.1, 149.2, 151.1, 151.6, 156.4, 161.1, 163.1, 166.6, 172.2, 174.2. HRMS (ESI) calculated $\mathrm{C}_{63} \mathrm{H}_{83} \mathrm{FN}_{18} \mathrm{O}_{13} \mathrm{Na} 1341.6269$ found 1341.6091.

\subsection{Reporter Activation Assays}

Growth assays to test the activation of the LEU2 reporter in the yeast strain V784Y were done in liquid culture as described previously [23]. Briefly, assays were performed by diluting the yeast from a saturated overnight culture to $2 \times 10^{5}$ cells/well in a sterile flat-bottom clear 96-well plate (Becton-Dickinson, Franklin Lakes, NJ, USA) with $150 \mu \mathrm{L}$ of the appropriate selective media containing either CID (10 $\mu \mathrm{M}$ unless otherwise indicated) or the equivalent amount of DMSO $(1 \% \mathrm{v} / \mathrm{v})$. The plates were wrapped with parafilm and incubated at $30{ }^{\circ} \mathrm{C}$ with shaking at $80 \mathrm{rpm}$. Every $24 \mathrm{~h}$ the absorbance at $600 \mathrm{~nm}$ was measured using a pre-heated plate reader (BioTek, Winooski, VT, USA). Cell suspensions were mixed by pipetting prior to each measurement.

To measure activation of the $L a c Z$ gene, the standard liquid $\beta$-Galactosidase assay described in the Yeast Protocols Handbook (PT3024-1 Clontech, Mountain View, CA, USA) was adapted to $150 \mu \mathrm{L}$ cultures grown in 96-well plates. Briefly, saturated overnight cultures were diluted 1:100 in SC + Gal/Raff -his-trp-ura media in sterile flat-bottom 96-well plates and incubated at $30{ }^{\circ} \mathrm{C}$ for $72 \mathrm{~h}$. Yeast cultures were collected and centrifuged at $21{ }^{\circ} \mathrm{C}$ at $16,000 \times g$ for $5 \mathrm{~min}$. The pellets were washed once with double-distilled water and resuspended in freshly prepared breaking buffer containing 1x protease inhibitor mix (P8340 Sigma, Gillingham, Dorset, UK), $100 \mathrm{mM}$ Tris- $\mathrm{HCl}$ pH8.0, $1 \mathrm{mM}$ DTT and 20\% v/v glycerol. Acid-washed beads were added to each tube to fill the volume up to the meniscus and the cells were broken by $10 \times 15 \mathrm{sec}$ pulses of vortexing, each pulse followed by $1 \mathrm{~min}$ incubation on ice. The spheroblast suspension was then solubilized in $0.1 \% \mathrm{w} / \mathrm{v}$ SDS for $10 \mathrm{~min}$ at $21^{\circ} \mathrm{C} .25 \mu \mathrm{L}$ of each lysate was used to measure total protein concentration by the standard microtiter Bradford assay (BioRad, Hercules, CA, USA). The rest of the extract was used for the $\beta$-galactosidase assay using CPRG (Roche, Indianapolis IN, USA) as substrate, as described in the Yeast Protocols Handbook (Clontech PT3024-1).

\section{Conclusions}

The development of a modular approach to the synthesis of triazole-containing chemical inducers of dimerisation (CIDs) has been described and used to prepare four CIDs, MTX-Cmpd2.2-2.5. The ability to prepare in a rapid manner a small family of CIDs enables the researcher to explore which linker length is the most suitable for a particular target identification study. In this case, our compound 2-based CIDs were then compared using the $\mathrm{Y} 3 \mathrm{H}$ approach with three of them giving a strong positive interaction with a known target of compound 2, TgCDPK1. Interestingly at longer time points, the triazole-containing CIDs MTX-Cmpd2.2-2.5, all showed less background growth compared to PEG-containing CID, MTX-Cmpd2.1. This novel observation may have implications for future $\mathrm{Y} 3 \mathrm{H}$ 
screening campaigns. The modular nature of the synthetic strategy used here will help to overcome the CID synthesis challenges currently encountered and should contribute to the $\mathrm{Y} 3 \mathrm{H}$ approach reaching its full potential as an unbiased target identification strategy.

\section{Supplementary Materials}

Detailed synthesis of aminoalkynes 6 and aminoazides 7 can be found in the supplementary information provided alongside ${ }^{1} \mathrm{H},{ }^{13} \mathrm{C}$ and 2D NMR spectra of ${ }^{t}$ Bu-MTX-cmpd2.2 and MTX-Cmpd2.2. This material is available free of charge at: http://www.mdpi.com/1420-3049/18/9/11639/s1.

\section{Acknowledgments}

We thank Alan Howard for assistance with statistical analysis and Virginia Cornish for providing yeast strains. We would also like to thank Catherine Botting and Sally Shirran for providing us with HR-MS data. This work was supported by US Public Health Service grant AI054961. NJW was a Royal Society University Research Fellow when this work began.

\section{Conflicts of Interests}

The authors declare no conflict of interest.

\section{References}

1. Althoff, E.A.; Cornish, V.W. A Bacterial Small-Molecule Three-Hybrid System Angew. Chem. Int. Ed. 2002, 41, 2327-2330.

2. Baker, K.; Sengupta, D.; Salazar-Jimenez, G.; Cornish, V.W. An optimized dexamethasonemethotrexate yeast 3-hybrid system for high-throughput screening of small molecule-protein interactions. Anal. Biochem. 2003, 315, 134-137.

3. Becker, F.; Murthi, K.; Smith, C.; Come, J.; Costa-Roldán, N.; Kaufmann, C.; Hanke, U.; Degenhart, C.; Baumann, S.; Wallner, W.; et al. A Three-Hybrid Approach to Scanning the Proteome for Targets of Small Molecule Kinase Inhibitors Chem. Biol. 2004, 11, 211-223.

4. Caligiuri, M.; Becker, F.; Murthi, K.; Kaplan, F.; Dedier, S.; Kaufmann, C.; Machl, A.; Zybarth, G.; Richard, J.; Bockovich, N.; Kluge, A.; Kley, N. A Proteome-Wide CDK/CRK-Specific Kinase Inhibitor Promotes Tumor Cell Death in the Absence of Cell Cycle Progression. Chem. Biol. 2005, 12, 1103-1115.

5. Caligiuri, M.; Molz, L.; Liu, Q.; Kaplan, F.; Xu, J.P.; Majeti, J.Z.; Ramos-Kelsey, R.; Murthi, K.; Lievens, S.; Tavernier, J.; Kley, N. MASPIT: Three-Hybrid Trap for Quantitative Proteome Fingerprinting of Small Molecule-Protein Interactions in Mammalian Cells. Chem. Biol. 2006, 13, 711-722.

6. Chidley, C.; Haruki, H.; Pedersen, M.G.N.; Muller, E.; Johnsson, K. A yeast-based screen reveals that sulfasalazine inhibits tetrahydrobiopterin biosynthesis. Nat. Chem. Biol. 2011, 7, 375-383.

7. Corson, T.W.; Aberle, N.; Crews, C.M. Design and Applications of Bifunctional Small Molecules: Why Two Heads Are Better Than One. ACS Chem. Biol. 2008, 3, 677-692. 
8. Cottier, S.; Mönig, T.; Wang, Z.; Svoboda, J.; Boland, W.; Kaiser, M.; Kombrink, E. The Yeast Three-Hybrid System as an Experimental Platform to Identify Proteins Interacting with Small Signaling Molecules in Plant Cells: Potential and Limitations. Front. Plant Sci. 2011, 2, 1-12.

9. Donald, R.G.K.; Zhong, T.; Wiersma, H.; Nare, B.; Yao, D.; Lee, A.; Allocco, J.; Liberator, P.A. Anticoccidial kinase inhibitors: Identification of protein kinase targets secondary to cGMP-dependent protein kinase. Mol. Biochem. Parasitol. 2006, 149, 86-98.

10. Jaeger, S.; Eriani, G.; Martin, F. Results and prospects of the yeast three-hybrid system. FEBS Lett. 2004, 556, 7-12.

11. Kley, N. Chemical Dimerizers and Three-Hybrid Systems: Scanning the Proteome for Targets of Organic Small Molecules. Chem. Biol. 2004, 11, 599-608.

12. Lefurgy, S.; Cornish, V. Finding Cinderella after the Ball: A Three-Hybrid Approach to Drug Target Identification. Chem. Biol. 2004, 11, 151-153.

13. Licitra, E.J.; Liu, J.O. A three-hybrid system for detecting small ligand-protein receptor interactions. Proc. Natl. Acad. Sci. 1996, 93, 12817-12821.

14. Maniataki, E.; Martinez de Alba, A.; Sägesser, R.; Tabler, M.; Tsagris, M. Viroid RNA systemic spread may depend on the interaction of a 71-nucleotide bulged hairpin with the host protein VirP1. RNA 2003, 9, 346-354.

15. Schneider, K.; Wang, Z.M.; Kaiser, E.; Kombrink, E. On the molecular mechanism of hormone action: hunting the jasmonate target(s). Curr. Topics Phytochem. 2008, 9, 1-16.

16. Vollmeister, E.; Haag, C.; Zarnack, K.; Baumann, S.; König, J.; Mannhaupt, G.; Feldbrügge, M. Tandem KH domains of Khd4 recognize AUACCC and are essential for regulation of morphology as well as pathogenicity in Ustilago maydis. RNA 2009, 15, 2206-2218.

17. Wurster, S.E.; Maher, L.J. Selections that optimize RNA display in the yeast three-hybrid system. RNA 2010, 16, 253-258.

18. Shepard, A.R.; Conrow, R.E.; Pang, I.-H.; Jacobson, N.; Rezwan, M.; Rutschmann, K.; Auerbach, D.; SriRamaratnam, R.; Cornish, V.W. Identification of PDE6D as a Molecular Target of Anecortave Acetate via a Methotrexate-Anchored Yeast Three-Hybrid Screen. ACS Chem. Biol. 2013, 8, 549-558.

19. Abida, W.M.; Carter, B.T.; Althoff, E.A.; Lin, H.; Cornish, V.W. Receptor-Dependence of the Transcription Read-Out in a Small-Molecule Three-Hybrid System. ChemBioChem 2002, 3, 887-895.

20. Henthorn, D.C.; Jaxa-Chamiec, A.A.; Meldrum, E. A GAL4-based yeast three-hybrid system for the identification of small molecule-target protein interactions. Biochem. Pharmacol. 2002, 63, 1619-1628.

21. Lin, H.; Abida, W.M.; Sauer, R.T.; Cornish, V.W. Dexamethasone-Methotrexate: An Efficient Chemical Inducer of Protein Dimerization In Vivo. J. Am. Chem. Soc. 2000, 122, 4247-4248.

22. Suwwan de Felipe, K.; Carter, B.T.; Althoff, E.A.; Cornish, V.W. Correlation between LigandReceptor Affinity and the Transcription Readout in a Yeast Three-Hybrid System. Biochemistry 2004, 43, 10353-10363.

23. Odell, A.V.; Tran, F.; Poupart, S.; Pathak, R.; Westwood, N.J.; Ward, G.E. Yeast three-hybrid screen identifies TgBRADIN as a novel negative regulator of Toxoplasma gondii bradyzoite differentiation. PLoS One 2013, submitted. 
24. Walton, J.G. A.; Patterson, S.; Liu, G.; Haraldsen, J.D.; Hollick, J.J.; Slawin, A.M.Z.; Ward, G.E.; Westwood, N.J. Synthesis and biological evaluation of functionalised tetrahydro-[small beta]carboline analogues as inhibitors of Toxoplasma gondii invasion. Org. Biomol. Chem. 2009, 7, 3049-3060.

25. Amara, J.F.; Clackson, T.; Rivera, V.M.; Guo, T.; Keenan, T.; Natesan, S.; Pollock, R.; Yang, W.; Courage, N.L.; Holt, D.A.; Gilman, M. A versatile synthetic dimerizer for the regulation of protein-protein interactions. Proc. Natl. Acad. Sci. 1997, 94, 10618-10623.

26. Spencer D.M; Wandless, T.J; Schreiber, S.L.; Crabtree, G.R. Controlling signal transduction with synthetic ligands. Science 1993, 262, 1019-1024.

27. Lu, G.; Lam, S.; Burgess, K. An iterative route to "decorated" ethylene glycol-based linkers. Chem. Commun. 2006, 2006, 1652-1654.

28. Biftu, T.; Feng, D.; Fisher, M.; Liang, G.-B.; Qian, X.; Scribner, A.; Dennis, R.; Lee, S.; Liberator, P.A.; Brown, C.; et al. Synthesis and SAR studies of very potent imidazopyridine antiprotozoal agents. Bioorg. Med. Chem. Lett. 2006, 16, 2479-2483.

29. Bonger, K.M.; van den Berg, R.J.; Heitman, L.H.; Ijzerman, A.P.; Oosterom, J.; Timmers, C.M.; Overkleeft, H.S.; van der Marel, G.A. Synthesis and evaluation of homo-bivalent GnRHR ligands. Bioorg. Med. Chem. 2007, 15, 4841-4856.

30. Gervay-Hague, J.; Du, W.; Denardo, S.; Natarajan, A. Construction of a multivalent SCFV through alkyne-azide 1,3-dipolar cycloaddition. WO 2007/112362 A2, 4 October 2007.

31. Klein, E.; DeBonis, S.; Thiede, B.; Skoufias, D.A.; Kozielski, F.; Lebeau, L. New chemical tools for investigating human mitotic kinesin Eg5. Bioorg. Med. Chem. 2007, 15, 6474-6488.

32. Kolb, H.C.; Finn, M.G.; Sharpless, K.B. Click Chemistry: Diverse Chemical Function from a Few Good Reactions. Angew. Chem. Int. Ed. 2001, 40, 2004-2021.

33. Kolb, H.C.; Sharpless, K.B. The growing impact of click chemistry on drug discovery. Drug Discov. Today 2003, 8, 1128-1137.

34. Rostovtsev, V.V.; Green, L.G.; Fokin, V.V.; Sharpless, K.B. A Stepwise Huisgen Cycloaddition Process: Copper(I)-Catalyzed Regioselective "Ligation" of Azides and Terminal Alkynes. Angew. Chem. Int. Ed. 2002, 41, 2596-2599.

35. Thirumurugan, P.; Matosiuk, D.; Jozwiak, K. Click Chemistry for Drug Development and Diverse Chemical-Biology Applications. Chem. Rev. 2013, 113, 4905-4979.

36. Robinson, C.R.; Sauer, R.T. Optimizing the stability of single-chain proteins by linker length and composition mutagenesis. Proc. Natl. Acad. Sci. 1998, 95, 5929-5934.

37. George, R.A.; Heringa, J. An analysis of protein domain linkers: their classification and role in protein folding. Protein Eng. 2002, 15, 871-879.

38. Nusinow, D.A.; Helfer, A.; Hamilton, E.E.; King, J.J.; Imaizumi, T.; Schultz, T.F.; Farre, E.M.; Kay, S.A. The ELF4-ELF3-LUX complex links the circadian clock to diurnal control of hypocotyl growth. Nature 2011, 475, 398-402.

39. Rietz, S.; Stamm, A.; Malonek, S.; Wagner, S.; Becker, D.; Medina-Escobar, N.; Corina Vlot, A.; Feys, B.J.; Niefind, K.; Parker, J.E. Different roles of Enhanced Disease Susceptibility1 (EDS1) bound to and dissociated from Phytoalexin Deficient4 (PAD4) in Arabidopsis immunity. New Phytol. 2011, 191, 107-119. 
40. Sheerin, D.J.; Buchanan, J.; Kirk, C.; Harvey, D.; Sun, X.; Spagnuolo, J.; Li, S.; Liu, T.; Woods, V.A.; Foster, T.; Jones, W.T.; Rakonjac, J. Inter- and intra-molecular interactions of Arabidopsis thaliana DELLA protein RGL1. Biochem. J. 2011, 435, 629-639.

Sample Availability: Samples of the compounds $\mathbf{3 a}-\mathbf{c}$ and $\mathbf{4 a - d}$ are available from the authors.

(C) 2013 by the authors; licensee MDPI, Basel, Switzerland. This article is an open access article distributed under the terms and conditions of the Creative Commons Attribution license (http://creativecommons.org/licenses/by/3.0/). 